酤 HARVARD Kennedy School

Faculty Research Working Papers Series

The Estimated Effects of the Euro on Trade: Why Are They Below Historical Effects of Monetary Unions Among Smaller Countries?

Jeffrey Frankel

John F. Kennedy School of Government - Harvard University

December 2008

RWP08-076

The views expressed in the HKS Faculty Research Working Paper Series are those of the author(s) and do not necessarily reflect those of the John F. Kennedy School of Government or of Harvard University. Faculty Research Working Papers have not undergone formal review and approval. Such papers are included in this series to elicit feedback and to encourage debate on important public policy challenges. Copyright belongs to the author(s). Papers may be downloaded for personal use only. 


\title{
The Estimated Effects of the Euro on Trade: Why Are They Below Historical Effects of Monetary Unions Among Smaller Countries?
}

\author{
Jeffrey Frankel \\ Harvard University and NBER
}

\author{
for NBER conference on Europe and the Euro, October 17-18, 2008 \\ Alberto Alesina \& Francesco Giavazzi, Organizers.
}

The author wishes to thank Francesco Giavazzi and Sylvana Tenreyo for comments, Clara Zverina for research assistance, and Ernesto Stein (who was originally going to be a co-author of this paper).

\begin{abstract}
Andy Rose (2000), followed by many others, has used the gravity model of bilateral trade on a large data set to estimate the trade effects of monetary unions among small countries. The finding has been large estimates: Trade among members seems to double or triple, that is, to increase by 100-200\%. After the advent of EMU in 1999, Micco, Ordoñez and Stein and others used the gravity model on a much smaller data set to estimate the effects of the euro on trade among its members. The estimates tend to be statistically significant, but far smaller in magnitude: on the order of $10-20 \%$ during the first four years. What explains the discrepancy? This paper seeks to address two questions. First, do the effects on intra-euroland trade that were estimated in the euro's first four years hold up in the second four years? The answer is yes. Second, and more complicated, what is the reason for the big discrepancy vis-à-vis other currency unions? We investigate three prominent possible explanations for the gap between 15\% and 200\%. First, lags. The euro is still very young. Second, size. The European countries are much bigger on average than most of those who had formed currency unions in the past. Third, endogeneity of the decision to adopt an institutional currency link. Perhaps the high correlations estimated in earlier studies were spurious, an artifact of reverse causality. Contrary to expectations, we find no evidence that any of these factors explains a substantial share of the gap, let alone all of it.
\end{abstract}

Key words:

bilateral trade, currency union, euro, Europe, European Monetary Union, EMU, gravity, monetary union, Rose

JEL classification numbers: F1, F33, F4. 


\section{The Estimated Effects of the Euro on Trade: Why Are They Below Historical Effects of Monetary Unions Among Smaller Countries?}

Andrew Rose’s 2000 paper, “One Money, One Market...” was perhaps the most influential international economics paper of the last ten years. Applying the gravity model to a data set that was sufficiently large to encompass a number of currency unions led to an eye-opening finding: members of currency unions traded with each an estimated three times as much as with otherwise-similar trading partners. Even if he had not included the currency union dummy, this paper would still have been important, because he had bilateral exchange rate variability on the list of variables explaining bilateral trade, and it was highly significant statistically. ${ }^{1}$ But the attention-grabber was that the currency union dummy had a far larger, and highly significant effect - the famous tripling estimate -- above and beyond the effect of bilateral variability per se. The Rose paper was of course motivated by the coming of EMU in 1999, even though estimates were necessarily based on historical data from (much smaller) countries who had adopted currency unions in the past.

\section{First post-1999 results on effects of the euro on European trade patterns}

By roughly the five year mark, 2004, enough data had accumulated to allow an analysis of the early effects of the euro on European trade patterns. The general finding was that that bilateral trade among euro members had indeed increased significantly, but that the effect was far less than the one that had been estimated by Rose on the larger data set of smaller countries. Micco, Ordoñez and Stein (2003) found in a data set of European countries that trade between pairs of the first 12 EMU-joiners rose significantly between 1999 and 2002, an estimated 15 \% beyond what could be explained by growth and other factors. The estimates of the euro effect in a larger set of 22 industrialized countries ranged from 6 to $26 \%$, depending on dummies. The authors expressed a preference for estimates that allowed for pair dummies, and produced a somewhat smaller estimate of the effect: 4-16\%. ${ }^{2}$ These magnitudes were less than in the Rose studies. As the authors pointed out, however, the effects were both statistically significant and also economically important, which is not bad considering that the sample covered only the first four years of the EMU, a period in which the euro did not even circulate in currency form.

\footnotetext{
${ }^{1}$ The finding that a fixed exchange rate in itself also produces a statistically significant increase in bilateral trade has more recently been confirmed by Klein \& Shambaugh (2006).

${ }^{2}$ Earlier, the preferred Micco, Ordoñez and Stein (2002) estimates of “differences in differences" showed that between 1992 and 2001 the boost to intra-EMU trade was about 18 to 35 percent, depending on whether using country-pair dummies, or conditioning on the standard gravity variables.
} 
Other evidence from the first five years confirmed the finding. Bun and Klaassen (2002, p.1) updated gravity estimates and found that "the euro has significantly increased trade, with an effect of $4 \%$ in the first year" and a long-run effect projected to be about 40 percent. Flam and Nordström (2006) found an effect of $26 \%$ in the change from 1995-98 to 2002-05. Berger and Nitsch (2005) and De Nardis and Vicarelli (2003) reported similarly positive results. More recently, Chintrakarn (2008) finds that two countries sharing the euro have experienced a boost in bilateral trade between 9 and 14\%. Overall, the central tendencies of these estimates seems to be an effect in the first few years on the order of $10-15 \% .^{3}$

Thus the trade effects of monetary union are not entirely limited to small countries. But they are far smaller than the tripling estimated by Rose. The central questions of this chapter are (1) what are the estimated effects, updated at the ten year mark, and (2) assuming they are similar to the $10-15 \%$ effects estimated by the early studies of euroland, what explains the large gap between the euro estimates and the tripling effects estimated by Rose and others using much larger historical data sets? Is it a matter of lags, so that the $10-15 \%$ can be expected to rise gradually over time, eventually reaching levels comparable with those estimated for currency unions that have been around for 100 years? Or is the currency union effect systematically smaller for large countries than for small countries? Or, even with the smaller countries, is the tripling merely an artifact of estimation problems associated with endogeneity and omitted variables. Finally, is there some effect (or lack thereof) peculiar to Europe?

\section{The Critiques}

Rose's remarkable tripling estimate has by now been replicated in various forms many times. But no sooner had he written his paper than the brigade to "shrink the Rose effect" ${ }^{4}$ - or to make it disappear altogether -- descended en masse. These critiques sometimes read to me as "guilty until proven innocent."

It is understandable that a threefold effect was greeted with much skepticism, as this is a very large number. There are five grounds for skepticism, as I classify them. Each of these arguments is potentially potent in the context of assessing the euro's effect on European trade patterns, if for no other reason than the claims that the Rose finding has always been spurious. But the critiques need to be assessed.

\footnotetext{
${ }^{3}$ Studies with price data have tended to be more mixed, but some confirm that the euro is facilitating arbitrage among the markets of member countries. Looking at price data across pairs of European cities, Rogers (2001, 2002) finds evidence of convergence, but in the 1990s. In the European auto market, Goldberg, Koujianou, and Verboven (2001) find gradual convergence over the period 1970-2000. Goldberg and Verboven (2004) nail down EMU, per se, as a significant determinant of this convergence. Other positive findings come from Allington, Kattuman and Waldman (2005) and Parsley and Wei (2001b). Engel and Rogers (2004) are more negative.

${ }^{4}$ The phrase is from Richard Baldwin (2006). Baldwin's survey of the critiques concludes in the end that there is a Rose effect, but that it is probably substantially smaller than a tripling. That is fine with me. If Rose had come up with a 50\% effect on trade from the beginning, everyone would have considered that very large and important.
} 
The first critique is the proposition that one cannot necessarily infer from crosssection evidence what would be the effect in real time of countries adopting a common currency. Most pre-1999 members of currency unions had essentially never had their own national currencies, but instead used an external currency at least since independence. In such cases as Panama or most of the CFA countries in Africa, the currency arrangement goes back more than a century. In other cases, such as the Eastern Caribbean Currency Area, the currency dates from post-war independence..

Second are allegations of missing variables. The statistical association between currency links and trade links might not be the result of causation running from currencies to trade but might arise instead because both sorts of links are caused by a third factor, such as colonial history, remaining political links, complementarity of endowments, or accidents of history. Another alleged missing variable is a country's "multilateral resistance" to trade or a more specific measure of remoteness from the rest of the world.

The third critique also concerns causality: the endogeneity of the currency decision. Countries choose as partners for currency links the neighbors with whom they trade the most, rather than the other way around. Perhaps the endogeneity of the currency union decision, and the simultaneity of other regional trade-promoting forces, have been stronger among developing countries than among European countries. In other words much of the correlation observed for currency unions among other countries may be spurious.

Fourth, the estimated effect on trade simply seems too big to be believable. While this judgment is explicitly a gut-reaction, it is widely shared. Furthermore, an influential argument by Van Wincoop, to the effect that the question has been mis-parameterized and that the true effects are substantially smaller, seems to support it.

Fifth, Rose's evidence came entirely from countries that were either small (e.g., Ireland, Panama) or very small (e.g., Kiribati, Greenland, Mayotte). Thus it was not clear that the estimates could be extended to larger countries. European economies tend to be large - some, particularly Germany, very large - while the set of non-EMU currency union countries tends to be small, some of them very small. If the currency union effect is substantially more important in small highly trade-dependent countries, that could readily explain the small estimates for Europe.

While each of these five arguments has some validity, to each there is a better response than one might expect.

\section{Times series dimension}

First, regarding the time dimension, a logical interpretation is that, even if the full comparative statics effect were to obtain in the very long run after a change in regime, they might not show up in the short run, due to very substantial lags. That would not be surprising, as we have evidence of long lags in the effects on bilateral trade of such variables as colonization and the formation of FTAs. 
Even 30 years may not be the long run effect. The effect may keep rising for a long time. Panama reports sending more than half its exports to the United States; perhaps one reason is that it has been on the US dollar for over a hundred years.

We know that other gravity influences leave an effect on bilateral trade many decades after the cause has been removed. One piece of evidence is the slow speed of adjustment in general estimated in models with lags. ${ }^{5}$ Another important example is the effect that colonial relationships have even decades after independence, and even after controlling for continuing linguistic, political, or other links. Consider as an illustration a trivia question: what is Congo's largest trading partner? Not one of its neighbors, nor a large country, as the simple gravity model would lead you to expect; it is Belgium, the old colonial master, with whom ties were abruptly severed almost 50 years ago. ${ }^{6}$ Even when the original reason for a high level of bilateral trade has disappeared, the stock of capital that firms have invested in the form of marketing and distribution networks, brand-name loyalty among customers, and so forth, lives on for many years thereafter. The word hysteresis is sometimes applied to this phenomenon, suggesting that the effect is considered to be permanent.

Subsequent research on currency unions using time-series data finds that a substantial share of the tripling that Rose had estimated from the cross-section data, which is presumably the long-run effect, shows up within a few decades of a change. Using a 1948-1997 sample that includes a number of countries which left currency unions during that period, Glick and Rose (2002) find that trade among the members was twice as high in the currency union period as afterward. This suggests that roughly twothirds of the tripling effect may be reached within three decades of a change in regime. (This reasoning assumes symmetry with respect to entry into and exit from currency unions.)

\section{Omitted variables}

The second objection concerns the possible influence of omitted factors. Rose in fact did a thorough job of controlling for common languages, colonial history, and remaining political links. ${ }^{7}$ The large estimated effect of a common currency remains. It seems very possible that there remain other omitted factors (e.g., accidents of history) that influence both currency choices and trade links. Nevertheless, Rose's various extensions of the original research - these robustness tests together with the time-series results (Glick and Rose) and the common use of fixed effects -reduce some of the force of this critique.

The omitted variable that is probably of greatest concern to the critics comes from the influential Anderson-Van Wincoop paper, and is usually called "multilateral

\footnotetext{
5 Eichengreen and Irwin (1998) . Frankel (1997) discusses lagged effects historically for the cases of FTAs and political unions.

${ }^{6}$ Kleiman (1976) finds that about one-quarter of the (2- to 4-fold) bias of colonial times remains for countries that have been independent for two decades. Anderson and Norheim find longer lags in the effects of colonial status . Wang and Winters (1991) and Hamilton and Winters (1992) find significant effects for UK ex-colonial relationships (though not French) as late as 1984-86.

${ }^{7}$ While it is admirable how many factors Rose controls for, I agree with Baldwin and also Melitz (2001) in regarding as a "nuisance” Rose’s persistent habit of calling these "nuisance parameters.” These coefficients are of interest in their own right, and also help gauge the persuasiveness of the overall model.
} 
resistance term". ${ }^{8}$ More concretely, in a cross-section context, the variable may come down to "remoteness." A country's remoteness is defined as average distance from all trading partners, a weighted average based on the sizes of the trading partners; it is expected to have a positive effect on trade between a pair of countries, controlling for the more obvious negative effect of the distance between them bilaterally. Baldwin and Van Wincoop are a bit fanatical on this point: anyone who omits the relevant terms is not fit to be received in polite society. ${ }^{9}$

The Anderson-Van Wincoop (2001) model is an important contribution, both as theoretical foundation for the gravity model and in offering an argument that some of the border effects may have been quantitatively over-estimated. Rose and van Wincoop (2001) find that taking multilateral resistance and trade-diversion into account should, a priori, knock the estimated value of the euro on bilateral trade down from tripling to 58\% (among the original euro members). But the model's insistence on the role of tradediversion may be too doctrinaire. If I understand correctly the aspect of the Andersonvan Wincoop theory that leads to numerical estimates of the effects of borders and currencies that are sharply reduced in magnitude (though still significant), it is the property that the elimination of borders or currency differences within a region theoretically entails substantial diversion of trade away from the rest of the world and thus an increase in multilateral resistance. But such trade-diversion from currency unions, whatever its basis in theory, is not observed in the data, by and large. ${ }^{10}$ Thus the argument for imposing the constraints from this particular theory may not be as strong as it otherwise would be. Furthermore, even if one goes along with van Wincoop in imposing the constraint, the currency union term apparently remains high (1) compared to its standard error, (2) compared to what we all thought ten years ago, and (3) compared to what happens to the FTA term when it too is knocked down by imposing the van Wincoop constraint.

\section{Causality problems}

The endogeneity of a country's choice of exchange regime is perhaps the most intractable problem with the Rose-style estimates. After all, optimum currency area theory suggests that countries should peg if they are small and open, and should peg to the partners with which they trade a lot. ${ }^{11}$ El Salvador decided to adopt the dollar because it traded a lot with the United States, rather than the other way around. In that case the Rose finding would be spurious. Controlling for exogenous third factors such as

\footnotetext{
${ }^{8}$ Baldwin wants to call it the "relative prices matter" term. It could also be called the "general equilibrium" term.

9 I am one of those who long ago included remoteness in some of my gravity estimates (though not all). I devoted two pages to the subject in Frankel (1997, 143-144), and noted that it sometimes makes a difference to the results. The resistance to Canadian-U.S. trade is an example where it makes a difference: Wei (1996) found that controlling for remoteness helped knock down the home country bias from around 10 to around 3. Another may be the finding of a huge apparent effect of Pacific Islanders adopting the Australian dollar, in Nitsch (2001).

${ }^{10}$ For example, the UK does not appear to have lost trade to euroland as a result of the euro. Begg, et al (2003), Frankel and Rose (2002), Frankel (2003), Micco, Ordoñez and Stein (2003), and Chintrakarn (2008).

${ }^{11}$ McKinnon (1963).
} 
colonial history is a partial correction, but not a complete one, because they don't completely determine trade patterns.

One might reasonably ask why the same logic would not apply equally to the decisions by European countries to join the euro. Clearly the countries that have been most firmly committed to European monetary integration from the beginning (say, Germany, the Netherlands and Luxembourg) have been those that were the most thoroughly integrated with each other anyway. Those that have stayed out tend to be those that are less integrated. If this is enough to produce a tripling in the context of other countries, why is the estimated effect so low in Europe?

Many of the critiques of the Rose results, after pointing out a problem of omitted variables or endogeneity or one of the other legitimate problems, offer a purported way to address it and then report that the currency union effect disappears. ${ }^{12}$ My own view is that many of these responses in effect throw out most of the data in the name of addressing the (correctly emphasized) issues of endogeneity or country size. Or they do something similar: put in a great many dummy variables or fixed effects, often one for every pair of countries. This approach seems these days to be considered not just good econometric practice, but essential; we are told that we are not allowed so much as a peek at evil studies that neglect to do this. But my view is that since the finding of statistical significance arose only when Rose put together a large enough data set for it to show up, ${ }^{13}$ there is not that much information gained in reducing the data set sharply and then noticing the loss in statistical significance. Most of the statistical power lies in the crosscountry variation. Throw that out, and one may be left with little. ${ }^{14}$

That said, the complete bilateral data set is so large and the statistical relationship is so strong that there is some firepower to spare, and it is worth using some of it to try to get at the problems of endogeneity and missing variables. Including fixed effects for countries and/or years has become standard. The results generally hold up. Adding fixed effects for pairs of countries in the basic specification is a bit more problematic, though reasonable as a test for robustness. Rose (2001) himself tried adding pair fixed effects to his original data set, and found that the currency union dummy lost all significance, while pointing out that it is hard to see how it could have been otherwise, since all the action is in the bilateral cross-section. The same with Pakko and Wall (2001). Klein (2002), who deliberately focuses on US bilateral data alone, is one of many examples of throwing out enough data until the results become insignificant. Persson (2001) is another, despite the virtues of the matching estimator. When Rose tries Persson's matching estimator on a larger data set, he finds a significant (though smaller) effect (2.6.3).

More persuasive still is a before-and-after study such as Glick and Rose. It eliminates the problem that Panama has always (since independence) been on the dollar because it has always traded with the US, much as Luxembourg has always had a currency union with Belgium (at least since the Latin Monetary Union of 1865), because

\footnotetext{
${ }^{12}$ See Rose (2001) for a reply to one, and his Web site (http://faculty.haas.berkeley.edu/arose/RecRes.htm\#CUTrade) for more.

${ }^{13}$ Earlier gravity studies had not found major evidence of currency link effects on bilateral trade, presumably because the data sets were too small to include many examples of countries with institutionally fixed exchange rates: Thursby and Thursby (1987), DeGrauwe (1988), Brada and Mendez (1988), and Frankel and Wei (1993, 1995, 1997).

${ }^{14}$ Frankel (1990).
} 
it has always traded with Belgium. Rather these results show that when a country enters or leaves a currency link, its bilateral trade responds accordingly. But none of this is to deny that endogeneity remains a likely problem. For example, an evolution in trade patterns may come first, with the currency decision following. In theory, Ireland may have switched its currency allegiance from British to the continent in response to shifting trade patterns rather than as a cause of them. Attempting to deal with the endogeneity problem should be a priority.

\section{Implausible magnitude of the estimate}

Fourth, although those who claim that the tripling number is too large to sound plausible have a point, they tend to neglect two counterarguments. In the first place, the estimated effect of currency unions is on the same order of magnitude as the estimated effects of FTAs or, if anything, larger. ${ }^{15}$ When one applies some of the variant estimation strategies, such as the Rose-van Wincoop re-parameterization, so that the estimated effect of currency unions falls, the estimated effects of regional trading arrangements tend to fall in tandem. The point estimates, significance levels, and necessary methodological qualifications, are comparable across the two kinds of unions: FTAs and currency unions. In the second place, the estimated effects of currency unions are almost as big as the famous estimated effects of borders (home bias), e.g., in the Canada-US context, which is at least as big as a factor of three. ${ }^{16}$ This home bias is surprising, but is a fact of life. Something needs to explain it, and there are not very many candidates other than exchange rate variability. Thus the Rose findings remain a challenge to the traditional views of international economists, who believed that trade barriers were far more important than either currency differences or other remaining barrier frictions.

\section{Country size}

The fifth critique was the claim that the result from pre-1999 currency unions are relevant only for small countries, which are highly trade dependent, but are less relevant for larger countries such as those in Europe. A partial response has been possible all along: there has been no evidence of the monetary union effect varying with size, within the available sample. But if one suspects a threshold effect, above which the monetary union effect diminishes, and one posits that euro members are the first to be big enough to lie above that threshold, then this could explain the gap. The question whether the largest economies are truly different can only be answered with data from those countries. Fortunately, the euro experiment is now almost ten years old, and so we should hope to be able to answer the question. But to do so we will have to expand our view beyond the sort of data set used by Micco, Ordoñez and Stein, which was limited to European countries or at most to the set of industrialized countries, and to nest it within the larger sort of data set used by Rose, which captures trade among all countries.

\footnotetext{
${ }^{15}$ Baldwin cites approvingly an assertion of Berger \& Nitsch (2005) that it is implausible, even crazy, to think that the trade effect of the euro could be as large as the trade effect of EU. But this finding is common econometrically. If critics were to apply the same tough standards to both customs unions and currency unions, they would likely find the estimated magnitude at least as large in the latter case as in the former. As traditionally specified, this is a tripling.

${ }^{16}$ McCallum (1995), Helliwell (1998), Wei (1996), and Nitsch (1990, 1991).
} 


\section{Econometric investigation of the euro-Rose gap in estimated effects}

The tasks addressed in the remainder of this paper are, first, to confirm that the effects of the euro to date, even if statistically significant, are still relatively small, even with the addition of the several extra years of data that are now available, and second, and more importantly, to try to explain the gap. Three candidate explanations for the gap are the most obvious possibilities:

- Time is needed for gradual adjustment.

- Currency union effects for large countries are fundamentally different from those for small countries.

- Earlier estimates from pre-1999 samples of currency unions were biased upward by endogeneity.

\section{Reproduction of findings for early euro years; jumping the gun}

We begin by reproducing the results in Micco, Ordoñez and Stein (2002), who estimated the effect of the euro on trade patterns for a relatively narrow sample: Europe (or, alternatively, all industrialized countries ) during the period 1992-2002. Table 1 does successfully replicate the results: pairs of euro countries enjoy greater bilateral trade, with a coefficient that first appears suddenly significant in 1998, and then gradually rises in level and significance, through 2002.

Why does the effect show up in 1998, the year before EMU? It is likely that currency unions, much as FTAs, can start to have substantial effects on trade patterns even before they have formally gone into effect. This pattern is familiar pattern in the data. ${ }^{17}$ The most obvious interpretation is that once the negotiations, which typically have been going on for many years, are far enough along that the union appears very likely to take place, businessmen move quickly to try to establish a position in what is expected to be a large new market opportunity, perhaps to get a "first mover advantage." This argument works best, theoretically, in the case of markets destined for imperfect competition. But even in perfectly competitive markets, firms might want to get started early if there are transition costs associated with rapid investment in a new market.)

Baldwin (section 5.1) regards as suspicious the striking fact that the estimated effect in euroland appears suddenly in 1998, even though EMU did not take effect until January 1999. Even allowing the principle that business perceptions of imminent monetary union can set the date, rather than waiting for 1999, he claims "right up to March 1998, skeptics doubted that monetary union would be a reality." But statistics from financial markets tend to identify June 1997 as the breakpoint in perceptions. ${ }^{18}$ So it is plausible that businesses had started reacting in a measurable way by 1998 .

Next we updated the results, since another four years of data have become available. We find that the effect of the euro on bilateral trade remains highly significant statistically during the years 2003-2006, but that the point estimate is no

\footnotetext{
${ }^{17}$ E.g., Frankel (1997).

${ }^{18}$ On June 15, 1997, implied probabilities of joining Germany in EMU in 1999 were 100\% for Belgium and France and over 70\% for Finland, Spain and Portugal (calculations from JP Morgan based on spreads in the interest rate swap market). A similar statistic from Goldman Sachs on the probability of EMU taking place on January 1, 1999, shot up above 75\% after the Stability Pact was agreed in June 1997.
} 
longer rising. Rather, it appears to have leveled off at approximately 0.1, still very far below the Rose estimates of doubling or tripling. In the EU-only sample, the coefficient on intra-euroland trade rises to a highly significant estimated level of .13-.16 in 2001-02, but does not rise any further in 2003-06. In the sample that includes all developed countries, the euro effect becomes significant in 2003, at .11, but does not continue its upward trend during 2004-2006. (See Table 2.)

\section{Effect of size}

Table 3 investigates whether the effects of monetary union diminish with the size of the countries involved. It adds an interactive size term, computed as the product of the sizes of the respective countries and the dummy variable for currency union membership. The intent is to explore the hypothesis that currency union effects on trade are bigger for small countries than for large countries, and that this might explain the relatively smaller effect in Europe. It is true that larger countries experience smaller boosts to intra-MU trade: the interactive term is statistically significant. But the effect is still not significant within non-EMU monetary unions. Rather it appears within EMU. The effect of EMU on bilateral trade remains, even after controlling for size. The threshold argument would lead one to expect that size had less effect within the set of European countries than within the set of other monetary unions. But this argument is not definitive. We need to imbed the sample of European or industrialized countries within a more comprehensive set of countries before we can pass judgment on the claim that size explains the difference in effects.

\section{Imbedding euro estimates in larger sample of countries and time.}

If neither size effects nor time lags can explain the gap between the euro estimates of a $10-15 \%$ effect and the Rose-style estimates of a tripling, what can explain the difference? To try to nail this down it is necessary to imbed the euro data set inside an updated version of the larger cross-country data sets employed by Rose and others. Micco, Stein and Ordonez, like some of their competitors, looked only at a set of European countries, or at most a set of rich countries. When we imbed the data set from Tables 1 and 2 inside the larger data set, we can explicitly control for size and a Europe dummy to try to isolate where the big gap arises.

What follows are step-by-step results leading from Micco, Ordonez and Stein up to the higher results (from the 15\% effect to the tripling effect). We pursue the step-by-step analysis in two different dimensions: first, we use the two samples that MSO use (developed countries and EU sample), as well as our full sample at every step to show what difference the sample makes. Second, we start with a sample for 1992-2006 (this is the start-date of MSO, but their dataset stopped at 2001). We then expand this to our full dataset from 1948-2006 to see what difference the addition of the earlier observations makes. We also show both fixed effects (with country-pair fixed effects and year effects) and OLS (with year fixed effects).

Table 5A shows the estimation results, followed by the corresponding graph, for the first step: the 1992-2006 sample with only one dummy for EMU (no EMU-time interactions). We see that the euro effect exceeds $10 \%$ only when estimated within the EU sample. The estimates for the effect of the EMU on bilateral trade using the full 
sample or developed country sample are lower, around 6\%, and they fail to be significant for the full sample. Using OLS instead of fixed effect estimators decreases the effect significantly for the full and developed country samples, but increases it to above $30 \%$ for the EU sample.

Table 5B, and the corresponding graphs that follow, remain in the 1992-2006 sample time frame, but add EMU-year interaction terms to the specification so that we can follow the evolution of the euro's effect over time. We can recreate (as we did above) the MSO results for the developed and EU samples that they used: Estimates are significant during the euro period. ${ }^{19}$ The effect of the euro on trade rises steadily from 1998, reaching the statistically significant level of .15-.17 in 2001-2002.

We have added four years to the sample, relative to the initial round of studies. The euro effect remains in the same range, and statistically significant. But it does not continue to increase over the period 2002-2006. For the author, the most surprising finding of this study was the absence of any evidence that the effects of the euro on bilateral trade have continued to rise during the second half of the eight-year history of the euro. This seems counter to historical experience in other countries with lags in bilateral trade effects from both currency union entries/exits and other factors.

The results become less clear when we apply the specification to the full sample of countries. (The effect appears slightly negative for the years 1993-1996, jumps up in 1997, and becomes negative again in 2005-2006; but none of these estimates is significant in the full sample. $)^{20}$ This might seem to justify the M-O-S strategy of having confined their estimation to samples of EU and developed countries, under the logic that developing countries are too different to be useful. The most important point to note for our purposes, however, is that the coefficient on non-EMU currency unions remains a significant .75 (under OLS ${ }^{21}$ ). The exponential of .75 is 2.1, so this is a doubling of bilateral trade. The existence of the gap between small estimates for the euro (not even significant in this sample) and big estimates for other monetary unions is still very much in evidence. But we need a longer time sample if we want to obtain more reliable estimates and sharpen our standard errors.

Table 6A and the subsequent graph show step 2: we now expand the dataset to 1948-2006, which covers almost 60 years of data. The graph reveals that a crucial difference between MSO and broader estimates was the sample size. While estimates of

\footnotetext{
19 The reader should not be confused by the EMU-year interactive effects in the OLS column, which in most years can be taken to be essentially zero. The coefficient to focus on is the dummy "Both Countries in EMU," which is a highly significant .354. One needs to add this coefficient to the year estimates. Look at the bar charts in the figures to see this. In 1996, the .354 coefficient is almost knocked out by the significant negative year effect. Thereafter, the it dominates.

${ }^{20}$ When we use OLS, estimates are positive only for the developed and EU samples, but seem strange - for the EU sample, they start rather high in 1993, decrease slightly until 1996, and then take off again until a high in 2004, and only 1994-1997 are significant.

${ }^{21}$ It loses some luster under fixed effects; but this is perhaps to be expected since there are only 15 years of observations and much of the variation in the data is eaten up by fixed effects and interactive year dummies.
} 
the euro's effect on trade continue to linger around 10-25\% for the developed and EU samples that MSO used, they have climbed dramatically to .9-1.0 for the full sample, which exponentially is 2.5-2.7 -- almost tripling. All these estimates are highly significant, now that we have more data with which to work. We have uncovered the possibility that the large gap is an artifact of the largely non-overlapping historical periods analyzed in the Rose and M-O-S studies (pre- and post-1999, respectively). Interestingly, the estimated trade effects of the euro are now even larger and more significant than the trade effects of non-EMU currency unions, rather than the other way around. Moreover, for those concerned with the van Wincoop view that the gravity specification used here overstates what would be the percentage effect of joining (or leaving) a monetary union, it is worth noting that the estimated coefficient of EMU is larger than that on the EU or other FTAs, and this is a comparison that stands up with fixed country effects.

There appears to be much useful information from including all 60 years of available data in addition to including developing countries in the entire sample, rather than restricting ourselves to post-1992 observations of European or rich countries. Estimates such as those for the coefficients on common border or common language shift substantially when the more complete data set is brought to bear. Only by using the entire sample can we uncover large short-term effects, over 100\% when using fixed effects estimation. Second, the trade effects in the year before a monetary union formally goes into operation are even larger, and apply equally to EMU as to other monetary unions.

Table 6B continues the analysis of the full 60-year data set, but now adds interaction effects between EMU and years before and after entry, and the same for NonEMU monetary unions. We aggregate over each 5-year interval, to cut down on the loss of degrees of freedom and because it is implausible to think that there are sharp changes between, say, years 19 and 20. The corresponding graphs show the interaction effects both for non-EMU currency unions and for EMU: The dark blue represents the full sample estimates for non-EMU currency union interactions with "1 yr prior to CU entry", "1-5 yrs post", "6-10 yrs post", "11-15 yrs post", "16-20 yrs post", "21-25 yrs post", "2630 yrs post". The light blue, red, and yellow bars represent the estimates for the interaction terms of EMU with different years prior and post EMU entry, based on the three different sample sizes (full: light blue, developed: red, EU: yellow). As there are no non-EMU currency unions in the developed sample, we only have the full sample estimate for the non-EMU currency union interactions with time.

The central puzzle addressed by this paper, the huge discrepancy between the euro effects to date and other monetary unions, seems to be sharply diminished here. It is true that in the one year prior to monetary union, the apparent effect is huge for non-euro monetary unions and that also in the first five years it is several times larger. Perhaps reverse causality is a particular problem in these cases. But in years 6-10, the difference between EMU and non-euro currency unions is much smaller.

That the trade effects fail to rise in years 6-10 relative to years 1-5 turns out to apply to other currency unions as much as to EMU, in fact more so. To help decide whether this is telling us that the long-run effect is reached within five years, we need to look at the out-years for the non-EMU cases (since, again, there are no EMU 
observations out farther than ten years). The long-run effects depend entirely on whether one looks at fixed-effects or simple OLS results. Under fixed effects, the impact of currency unions continue to decline after 10 years (and in fact appear to go negative). Perhaps this has something to do with decreasing effects of colonial legacies. When using OLS instead of fixed effects, the estimated effects remain positive throughout the period (but fail to be significant, and even at the 30-year mark do not rise above the effect in the first 10 years). We have not yet thought of a reason for this discrepancy. But there is no evidence here that any of the observed euro-noneuro discrepancy in estimates is due to lags.

\section{Natural experiments to isolate causality}

The problem of endogeneity is probably the most serious stumbling block in interpreting the Rose findings as a causal relationship between the currency decision and trade patterns. Even when one controls for many other determinants of bilateral trade geographic, historical, linguistic - one can't escape entirely from the concern that there are missing variables that determine bilateral trade, and that the currency regime decision in turn reacts to trade, rather than the other way around. The OLS results reported in the previous section may give cause for worry that the high correlations in the year before monetary union, and in the five years after, are due to reverse causality, that the Eastern Caribbean countries form a currency union because their trade with each other is increasing, rather than the other way around. ${ }^{22}$

One way to address the causality problem is before-and-after case studies. There are a few uni-observational case studies. One example is the case of Ireland. Thom and Walsh (2002) focus on Ireland's abandonment of pound sterling in 1979; Dwane, Lane and McIndoe (2006) include also Ireland's adoption of the euro in 1999. There are strong trends in the share of Irish trade, away from the UK and toward euroland. But it is not possible statistically to discern effects of the two currency changes independently of the effects of Ireland's earlier accession to the EC or of the longer term trend. ${ }^{23}$

Another example is the Czech-Slovak breakup of 1993, which had a substantial negative effect on bilateral trade. ${ }^{24}$ It is viewed as more supportive of the Rose effect, apparently because a customs union was retained. But we know that political borders such as the one that divided the new Czech and Slovak Republics at the same time that the two adopted separate currencies have effects at least as large as conventional trade barriers.

As noted, Glick and Rose (2002) put together a huge data set covering the entire postwar period, which includes enough additional examples like the breaking of the Irish-

\footnotetext{
${ }^{22}$ I have a harder time, however, seeing how such reverse causality could explain the results with fixed effects, or the Glick-Rose estimates.

${ }^{23}$ The case examined is potentially one of the more important ones, as Ireland is one of the largest countries in the sample of countries that entered or left a currency union in the period between the 1960s and 1999.

But the lack of statistically significant findings is probably to be expected, given the other ongoing developments and the very small number of data points.

24 Frankel (1997, 121-122), Fidrmuc, Horvath, and Fidrmuc (1999), Fidrmuc and Fidrmuc (2001).
} 
pound link and Czech-Slovak link to get statistical significance out of the time series dimension. Indeed, they are able to do so even when including pair-specific dummies, thereby giving up the power in the cross-section variation. The beauty of fixed effects is indeed that they take account of time-invariant facts, observed or unobserved; so Glick and Rose's still significant results are very persuasive. As usual, the authors try lots of robustness checks. This might have been enough to satisfy the hard-line skeptics. ${ }^{25}$

But it was not. For one thing, most of the Glick-Rose results are not only from small countries, but also from instances of currency unions breaking up rather than forming, so that one cannot be sure that they apply equally to an example of large countries uniting in a currency union. For another thing, the decision to join a currency union, including the decision by Ireland or Slovenia to join EMU, could be misleadingly correlated with a shift in trade patterns toward continental Europe, either because:

- such a shift is a political goal, encouraged by other means as well, or

- trade is shifting in this direction for natural economic reasons, and policy-makers want to reduce foreign exchange costs for importers and exporters.

It would be useful to try some more real-time experiments. A useful comparison would be among the Nordic countries: Finland (which joined the euro along with the EU, while suffering an exogenous loss of trade with the Soviet Union after 1990), Sweden (which joined the EU but not the euro) and Norway (which has joined neither). But even if these interesting experiments were to produce the finding that the euro-joiners experienced increased bilateral trade with euroland, relative to the others, the critics could still plausibly claim endogeneity. Perhaps Finland joined the euro as a result of stronger political commitments to European integration than the others had, and perhaps this commitment is reflected in other trade-reallocating forces that are not the causal result of the euro itself. It might also be interesting to look at the case of Switzerland, the one country in the heart of Europe never to join the EU or EMU despite sharing borders and languages with four countries.

We here propose a sort of "natural experiment" designed to be as immune as possible from this sort of endogeneity argument. The experiment is the effect on bilateral trade of African CFA members of the French franc's 1999 conversion to the euro. The long-time link of CFA currencies to the French franc has clearly always had a political motivation. So CFA trade with France could not in the past reliably be attributed to the currency link, perhaps even after controlling for common language, former colonial status, etc. But with the advent of the euro, 14 CFA countries woke up in the morning and suddenly found themselves with the same currency link to Germany, Austria, Finland, Portugal, etc., as they had with France. There was no economic/political motivation on the part of the African countries that led them to an arrangement whereby they were tied to these other European currencies. Thus if CFA trade with these other European countries has risen, that suggests a euro effect that we can declare causal.

\footnotetext{
${ }^{25}$ I don't agree with the admonishment (e.g., Tenreyo, 2004) that they should try all the robustness checks at the same time, rather than one by one. One-by-one is the way to keep the volume of output manageable. Furthermore, I don't see as interesting an algorithm that checks whether trying every possible permutation can eventually produce some equation in which the currency union coefficient loses significance.
} 
Table 7A reports results. The dummy variable representing when one partner is a CFA country and the other a euro country has a highly significant coefficient of .57.

Taking the exponent, the point estimate is that the euro boosted bilateral trade between the relevant African and European countries by 76\%. Table 7B looks at the effects over time. The apparent timing of the effect is not ideal. It appears to jump to .64 in 1997 (two years before EMU), then to remain around .50 until 2002, and subsequently decline. Still, it is informative that this natural experiment produces such high estimates for the trade effects of an exogenous currency link.

\section{Conclusion}

This paper seeks to explain the discrepancy between estimates of the euro's effect on trade among members - about $15 \%$ in our results, as in those of earlier authors - and estimates of the effects of other earlier currency unions in large sample of countries - on the order of 200\%. It examines three obvious suspects. First, lags. The euro is still very young. We do find an upward trend in the trade effect during 1999-2004; but surprisingly we find no tendency during 2005-2006 for the euro's effect to have risen above the level that it had attained by 2004 (15\%). Second, size. The European countries are much bigger than most of those who had formed currency unions in the past. But the effect of a currency union does not appear to diminish discernibly with country size. Third, endogeneity of the decision to adopt an institutional currency link. Perhaps the high correlations estimated in earlier studies were spurious, an artifact of reverse causality. But we examine the natural experiment of trade between CFA countries and (non-Francophone) euro members and find a strong switch that in this case is unlikely to be the artifact of an endogenous currency decision. In short, we find no evidence that any of these factors explains any share of the gap, let alone all of it.

What we find instead is a surprising new suspect: results reported here suggest that the discrepancy might stem from sample size. If one estimates the effects of the euro versus other monetary unions in a large sample that includes all countries and all years, thereby bringing to bear as much information as possible on questions such as the proper coefficients on common border and common language in a gravity model, then the effect of the euro in the first eight years appears to be large, even comparable with the effect of the other non-euro monetary unions. It is hard to believe, however, that the true effect of the euro has indeed been this large; if intra-euroland trade had doubled or tripled since 1999, we would see it in the raw data and would not need to run a regression. Perhaps it is best to summarize the conclusions of the paper by saying that each of the three obvious suspects - lags, size, and endogeneity - has an apparent alibi; but the true perpetrator remains at large. 


\section{References}

Allington, N.F.B., P. Kattuman and F. Waldmann, 2005, “One Money, One Market, One Price,” International Journal of Central Banking .vol.1, no. 3, 73-115.

Anderson, James, 1979, "The theoretical foundation for the gravity equation," American Economic Review 69, 106-116.

Anderson, James, and Eric van Wincoop, 2001, "Gravity with gravitas: a solution to the border puzzle,” NBER Working Paper 8079, American Economic Review.

Baldwin, Richard, 2006, “The Euro's Trade Effects,” in What effects is EMU having on the euro area and its member countries?, European Central Bank, Frankfurt.

Baldwin, Richard and Daria Taglioni, 2004 "Positive OCA Criteria: Microfoundations for the Rose Effect,” Graduate Institute of International Studies, March.

Begg, David, et al, 2003, The Consequences of Saying No, An Independent Report into the Economic Consequences of the UK Saying No to the Euro, Commission on the UK Outside the Euro, London.

Brada, Josef C., 1993, "Regional Integration in Eastern Europe: Prospects for Integration Within the Region and with the European Community," in New Dimensions in Regional Integration, ed. by Jaime De Melo and Arvind Panagariya (Cambridge, UK: Cambridge University Press).

Bun, Maurice, and Franc Klaassen, 2002, “Has the Euro Increased Trade?” (unpublished; Amsterdam: University of Amsterdam). Tinbergen Institute Discussion Paper, TI 2002-108/2. Available via the Internet: http://www.eabcn.org/research/documents/bun_klaasen02.pdf .

Chintrakarn, Pandej, 2008, "Estimating the Euro Effects on Trade with Propensity Score Matching," Review of International Economics, 16, no. 1, pp. 186-198, February.

De Nardis, Sergio and Claudio Vicarelli, 2003, "Currency Unions and Trade: The Special Case of EMU”, World Review of Economics, 139 (4): 625-649.

Dwane, Christine, Philip Lane, and Tara McIndoe, 2006, "Currency Unions and Irish External Trade, IIIS Discussion Paper No. 189, Institute for International Integration Studies, Trinity College, Dublin.

Eichengreen, Barry, and Douglas Irwin. 1998, "The Role of History in Bilateral Trade Flows,” in The Regionalization of the World Economy, ed. by Jeffrey Frankel (Chicago: University of Chicago Press).

Engel, Charles, and John Rogers, 1996, “How Wide Is the Border?” American Economic Review, Vol. 86 (December), pp. 1112-25.

, 1998, "Regional Patterns in the Law of One Price: The Roles of Geography versus Currencies," The Regionalization of the World Economy, Jeffrey Frankel, ed. (Chicago: University of Chicago Press).

, 2004, “European Product Market Integration After the Euro,” Economic Policy, vol.19, no.39, 347-384.

Fidrmuc, Jan, Julius Horvath, and Jarko Fidrmuc, 1999, “The Stability of Monetary Unions: Lessons from the Breakup of Czechoslovakia,” Journal of Comparative Economics, 27, no. 4, Dec., 752-781. 
Flam, Harry, and Hakan Nordstrom, 2003, "Trade Volume Effects of the Euro: Aggregate and Sector Estimates,” Institute for International Economic Studies, Stockholm.

Frankel, Jeffrey, 1997, Regional Trading Blocs in the World Trading System (Washington: Institute for International Economics).

— Cycle Correlations,” in Submissions on EMU from Leading Academics (London; H.M. Treasury).

,2005, "Real Convergence and Euro Adoption in Central and Eastern Europe: Trade and Business Cycle Correlations as Endogenous Criteria for Joining EMU,” Euro Adoption in the Accession Countries - Opportunities and Challenges (International Monetary Fund: Washington DC), edited by Susan Schadler. KSG working paper RWP04-039.

Frankel, Jeffrey, and Andrew Rose, 2002, "An Estimate of the Effect of Common Currencies on Trade and Income,” Quarterly Journal of Economics, Vol. 117 (May), 437-466.

Frankel, Jeffrey, and Shang-Jin Wei, "Trade Blocs and Currency Blocs" NBER Working Paper 4335. In The Monetary Future of Europe, Guillermo de la Deheza, et al, eds., Centre for Economic Policy Research: London, 1993.

and Shang Jin Wei, 1995a, "Emerging Currency Blocs," in The International Monetary System: Its Institutions and Its Future, ed. by Hans Genberg (Berlin: Springer).

and Shang Jin Wei, 1995b, "European Integration and the Regionalization of World Trade and Currencies: The Economics and the Politics," in Monetary and Fiscal Policy in an Integrated Europe, ed. by Barry Eichengreen, Jeffry Frieden, and Jurgen von Hagen (Heidelberg: Springer-Verlag).

and Shang Jin Wei, 1997, "Regionalization of World Trade and Currencies: Economics and Politics," in The Regionalization of the World Economy, J. Frankel, editor, University of Chicago Press, Chicago.

Glick, Reuven, and Andrew Rose, 2002, "Does a Currency Union Affect Trade? The Time Series Evidence,” European Economic Review, Vol. 46 (June), pp. 1125-51.

Hamilton, Carl, and L.Alan Winters. 1992. "Opening Up International Trade in Eastern Europe," Economic Policy (April).

Helliwell, John, 1998, How Much Do National Borders Matter? (Washington: Brookings Institution Press).

Kleiman, Ephraim, 1976, "Trade and the Decline of Colonialism," The Economic Journal 86, September, 459-480.

Klein, Michael, 2002, “Dollarization and Trade.” NBER working paper 8879, April.

Klein, Michael, and Jay C. Shambaugh, 2006, "Fixed Exchange Rates and Trade.” Journal of International Economics, 70 (2), 359-383.

McCallum, John, 1995, "National Borders Matter: Canada-U.S. Regional Trade Patterns,” American Economic Review, 85 (June), pp. 615-23.

McKinnon, Ronald, 1963, “Optimum Currency Areas,” American Economic Review, Vol. 53 
(September), pp. 717-24.

Melitz, Jacques, 2001, “Geography, Trade and Currency Union,” University of Strathclyde, July, and CEPR Discussion Paper, No. 2987.

Micco, Alejandro, Ernesto Stein, and Guillermo Ordoñez, 2002, Should the UK Join EMU?

(Washington: Inter-American Development Bank).

_ 2003, “The Currency Union Effect on Trade: Early Evidence from EMU,” Economic Policy, Vol. 18 (October), pp. 315-43.

Nitsch, Volker, 1991, National Borders and International Trade: Evidence from the European Union (Berlin: Bankgesellschaft).

, 2000, "National Borders and International Trade: Evidence from the European Union

"Canadian Journal of Economics, November 2000, Volume 33, 1091-1105.

__ 2001, "Honey, I Shrunk the Currency Union Effect on Trade,” Bankgesellshaft Berlin, May.

Pakko, Michael R. and Howard J. Wall, 2001, "Reconsidering the Trade-Creating Effects of a Currency Union”, Federal Reserve Board of St. Louis Review, 83-5, 37-45.

Parsley, David, and Shang-Jin Wei, 2001, "Explaining the Border Effect: The Role of Exchange Rate Variability, Shipping Costs, and Geography,” Journal of International Economics, Vol. 55 (October), 87-105.

— , 2001b, "Limiting Currency Volatility to Stimulate Goods Market Integration: A Price Based Approach,” NBER Working Paper No. 8468 (Cambridge, Massachusetts: National Bureau of Economic Research).

Persson, Torsten (2001) “Currency Unions and Trade: How Large is the Treatment Effect?”, Economic Policy 33, 435-448.

Rose, Andrew, 2000, “One Money, One Market: Estimating The Effect of Common Currencies on Trade,” Economic Policy, Vol. 15 (April), 7-45.

$449-461$.

, 2001, “Currency Unions and Trade: The Effect Is Large,” Economic Policy, (October) 33, 2004, “A Meta-Analysis of the Effect of Common Currencies on International Trade,” NBER WP no. 10373, March.

Rose, Andrew K. and Eric van Wincoop (2001) "National Money as a Barrier to Trade: The Real Case for Monetary Union,” American Economic Review, 91-2, 386-390.

Tenreyro, Sylvana, 2001, “On the Causes and Consequences of Currency Unions,” Harvard University.

Thom, Rodney, and Brendan Walsh, 2002, "The Effect of a Common Currency on Trade: Ireland Before and After the Sterling Link,” European Economic Review, 46, no. 6, June, p. 1111-1123.

Wang, Zhen Kun, and L.Alan Winters, 1991, "The Trading Potential of Eastern Europe," Centre for Economic Policy Research Discussion Paper No. 610, November, London, UK. 
Table 1: Recreation of estimated effects on bilateral trade patterns in the first three years of the euro

\section{Re-creation of Micco, Stein \& Ordonez (2003) \\ on their original data sample and methodology}

Micco, Ordonez \& Stein (2003): EMU I mpact on Trade - Data from 1992 - 2002.

Includes Year and Country-Pair Fixed Effects.

\begin{tabular}{|c|c|c|c|c|c|c|}
\hline & \multicolumn{3}{|c|}{ Developed Sample } & \multicolumn{3}{|c|}{ EU Sample } \\
\hline & Coefficient & Std. Error & & Coefficient & Std. Error & \\
\hline EMU2 - 1993 & -0.0176 & 0.0331 & & -0.0068 & 0.0295 & \\
\hline EMU2 - 1994 & 0.0377 & 0.0337 & & 0.0246 & 0.0296 & \\
\hline EMU2 - 1995 & 0.0512 & 0.0340 & & 0.0162 & 0.0297 & \\
\hline EMU2 - 1996 & 0.0359 & 0.0345 & & 0.0000 & 0.0296 & \\
\hline EMU2 - 1997 & 0.0443 & 0.0350 & & 0.0175 & 0.0296 & \\
\hline EMU2 - 1998 & 0.0981 & 0.0358 & $* * *$ & 0.0637 & 0.0296 & $* *$ \\
\hline EMU2 - 1999 & 0.1166 & 0.0360 & $* * *$ & 0.0731 & 0.0297 & $* *$ \\
\hline EMU2 - 2000 & 0.1036 & 0.0367 & $* * *$ & 0.0762 & 0.0300 & $* * *$ \\
\hline EMU2 - 2001 & 0.1351 & 0.0369 & $* * *$ & 0.1662 & 0.0298 & $* * *$ \\
\hline EMU2 - 2002 & 0.1544 & 0.0368 & $* * *$ & 0.1644 & 0.0297 & $* * *$ \\
\hline Log of Product of Real GDPs & 1.1382 & 0.0464 & $* * *$ & 1.0620 & 0.0520 & $* * *$ \\
\hline Free Trade Agreement & -0.0097 & 0.0188 & & 0.0453 & 0.0300 & \\
\hline EU & 0.0095 & 0.0239 & & -0.0470 & 0.0467 & \\
\hline EU Trend & -0.0008 & 0.0014 & & -0.0013 & 0.0035 & \\
\hline Real Exchange Rate of Country 1 & -0.1737 & 0.0453 & $* * *$ & -0.1872 & 0.0627 & **** \\
\hline Real Exchange Rate of Country 2 & -0.2643 & 0.0518 & $* * *$ & 0.3738 & 0.0885 & $* * *$ \\
\hline Observations & 2541 & & & 1001 & & \\
\hline Within $\mathrm{R}^{2}$ & 0.462 & & & 0.671 & & \\
\hline Between $\mathrm{R}^{2}$ & 0.686 & & & 0.784 & & \\
\hline Overall $\mathrm{R}^{2}$ & 0.684 & & & 0.783 & 15 & \\
\hline
\end{tabular}

Notes: $*$ significant at the $10 \%$ level; $* *$ significant at the $5 \%$ level; $* * *$ significant at the $1 \%$ level

\section{Finding: $€$ effect reached $14-18 \%$ by 2001}

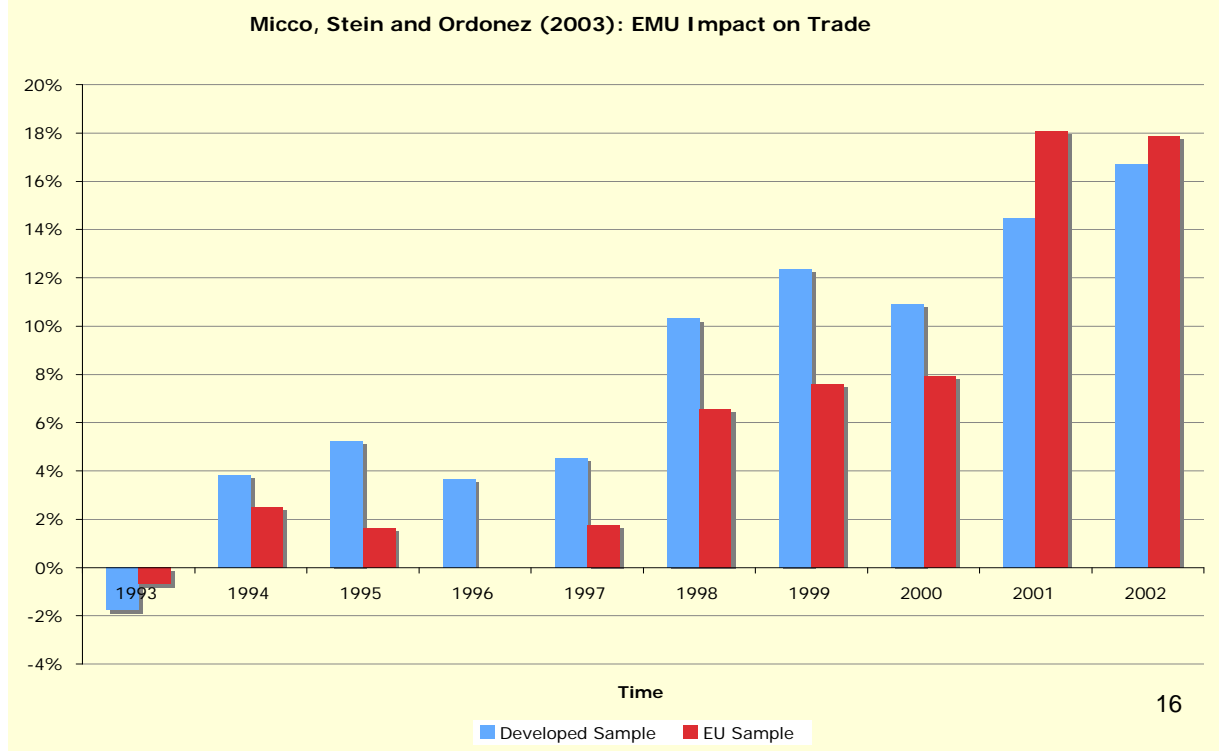


Table 2: Update of Table 1 -

creation of estimated effects on bilateral trade patterns in the first eight years of the euro

\section{Update: $€$ effect continues strong, 2001-2006}

EMU I mpact on Trade - I ncludes Data from 1992 - 2006.

Includes Year and Country-Pair Fixed Effects.

\begin{tabular}{|c|c|c|c|c|c|c|}
\hline & \multicolumn{3}{|c|}{ Developed Sample } & \multicolumn{3}{|c|}{ EU Sample } \\
\hline & Coefficient & Std. Error & & Coefficient & Std. Error & \\
\hline EMU2 - 1993 & -0.0489 & 0.0457 & & -0.0137 & 0.0352 & \\
\hline EMU2 - 1994 & -0.0297 & 0.0463 & & -0.0060 & 0.0352 & \\
\hline EMU2 - 1995 & -0.0258 & 0.0458 & & -0.0113 & 0.0352 & \\
\hline EMU2 - 1996 & -0.0300 & 0.0461 & & -0.0132 & 0.0352 & \\
\hline EMU2 - 1997 & -0.0138 & 0.0464 & & 0.0007 & 0.0352 & \\
\hline EMU2 - 1998 & 0.0315 & 0.0463 & & 0.0453 & 0.0352 & \\
\hline EMU2 - 1999 & 0.0205 & 0.0468 & & 0.0707 & 0.0358 & $* *$ \\
\hline EMU2 - 2000 & -0.0064 & 0.0469 & & 0.0719 & 0.0358 & $* *$ \\
\hline EMU2 - 2001 & 0.0650 & 0.0469 & & 0.1621 & 0.0355 & $* * *$ \\
\hline EMU2 - 2002 & 0.0698 & 0.0469 & & 0.1306 & 0.0354 & $* * *$ \\
\hline EMU2 - 2003 & 0.1102 & 0.0469 & $* *$ & 0.1334 & 0.0354 & $* * *$ \\
\hline EMU2 - 2004 & 0.1160 & 0.0467 & $* * *$ & 0.1507 & 0.0354 & $* * *$ \\
\hline EMU2 - 2005 & 0.0940 & 0.0469 & $* *$ & 0.1385 & 0.0354 & $* * *$ \\
\hline EMU2 - 2006 & 0.0806 & 0.0481 & $*$ & 0.1450 & 0.0354 & $* * *$ \\
\hline Log of Product of Real GDPs & 0.6623 & 0.0378 & $* * *$ & 0.4090 & 0.0341 & $* * *$ \\
\hline Free Trade Agreement & 0.0066 & 0.0163 & & -0.0669 & 0.0232 & $* * *$ \\
\hline EU & (dropped) & & & (dropped) & & \\
\hline EU Trend & 0.0000 & 0.0017 & & -0.0019 & 0.0015 & \\
\hline Real Exchange Rate of Country 1 & -0.0184 & 0.0032 & $* * *$ & 0.0006 & 0.0029 & \\
\hline Real Exchange Rate of Country 2 & -0.0004 & 0.0027 & & 0.0074 & 0.0024 & $* * *$ \\
\hline Observations & 2850 & & & 1170 & & \\
\hline Within $\mathrm{R}^{2}$ & 0.998 & & & 0.999 & & \\
\hline Between R ${ }^{2}$ & 0.650 & & & 0.804 & & \\
\hline Overall $\mathrm{R}^{2}$ & 0.920 & & & 0.929 & 17 & \\
\hline
\end{tabular}

Notes: $*$ significant at the $10 \%$ level; $* *$ significant at the $5 \%$ level; $* * *$ significant at the $1 \%$ level 
Table 3: CU effect diminishes with size only within EMU, but not among other countries With Currency Union and EMU Dummies, Interaction Variable between Currency Union and Country Size and Elapsed Time Variables. With Year Fixed Effects. Based on 1948 - 2006 Data.

\begin{tabular}{|c|c|c|c|c|}
\hline Log of Bilateral Trade & $\begin{array}{l}\text { OLS } \\
\text { Gravity Estimates }\end{array}$ & & $\begin{array}{r}\text { Fixed Effects } \\
\text { (Country-Pair FE) } \\
\end{array}$ & \\
\hline Currency Union (CU) & $\begin{array}{r}1.1778 \\
(2.5491)\end{array}$ & & $\begin{array}{r}-2.8473 \\
(0.5906)\end{array}$ & $\star \star \star *$ \\
\hline EMU & $\begin{array}{l}15.3995 \\
(7.5823)\end{array}$ & ** & (dropped) & \\
\hline CU * Log Product of Real GDPs & $\begin{array}{r}-0.0172 \\
(0.0550)\end{array}$ & & $\begin{array}{r}0.0655 \\
(0.0132)\end{array}$ & 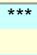 \\
\hline EMU * Log Product of Real GDPs & $\begin{array}{r}-0.2695 \\
(0.1539)\end{array}$ & * & $\begin{array}{r}0.0186 \\
(0.0310)\end{array}$ & \\
\hline Log Distance & $\begin{array}{r}-0.8772 \\
(0.0456)\end{array}$ & 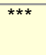 & $\begin{array}{r}0.3096 \\
(0.0106)\end{array}$ & 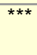 \\
\hline Log Product Real GDPs & $\begin{array}{r}0.7458 \\
(0.0123)\end{array}$ & 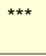 & $\begin{array}{r}0.1045 \\
(0.0169)\end{array}$ & *** \\
\hline Log Product Real GDP/Capita & $\begin{array}{r}0.0242 \\
(0.0151)\end{array}$ & & $\begin{array}{r}1.0935 \\
(0.0160)\end{array}$ & 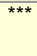 \\
\hline Common Language & $\begin{array}{r}0.2589 \\
(0.0746)\end{array}$ & 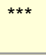 & $\begin{array}{r}-0.0407 \\
(0.0179)\end{array}$ & ** \\
\hline Common Land Border & $\begin{array}{r}0.0746 \\
(0.1854)\end{array}$ & *** & $\begin{array}{r}-0.4764 \\
(0.0504)\end{array}$ & 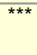 \\
\hline Regional FTA Membership & $\begin{array}{r}0.4199 \\
(0.1669)\end{array}$ & *** & $\begin{array}{r}0.0079 \\
(0.0384)\end{array}$ & \\
\hline \# Landlocked & $\begin{array}{r}-0.4382 \\
(0.0642)\end{array}$ & 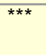 & $\begin{array}{r}0.2127 \\
(0.0152)\end{array}$ & 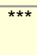 \\
\hline Area & $\begin{array}{r}-0.1048 \\
(0.0114)\end{array}$ & 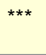 & $\begin{array}{l}-0.1123 \\
(0.0024)\end{array}$ & *** \\
\hline Common Colonizer & $\begin{array}{r}0.4360 \\
(0.1306)\end{array}$ & $\star \star \star *$ & $\begin{array}{r}0.0715 \\
(0.0285)\end{array}$ & 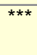 \\
\hline Current Colony / Colonizer & $\begin{array}{r}1.7076 \\
(0.4883)\end{array}$ & 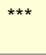 & $\begin{array}{r}0.4120 \\
(0.0976)\end{array}$ & *** \\
\hline Ever Colony / Colonizer & $\begin{array}{r}0.0731 \\
(0.1189)\end{array}$ & & $\begin{array}{l}-1.1098 \\
(0.0407)\end{array}$ & $\star \star \star *$ \\
\hline Common Country & $\begin{array}{r}2.4202 \\
(3.2544)\end{array}$ & & (dropped) & \\
\hline Intercept & $\begin{array}{r}-23.2333 \\
(0.5598)\end{array}$ & 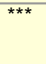 & $\begin{array}{r}-6.7655 \\
(0.6212)\end{array}$ & 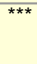 \\
\hline Observations & 297,322 & & 297,322 & \\
\hline $\begin{array}{l}\mathrm{R}^{2}: \text { OLS } \\
\mathrm{R}^{2}: \text { within } \\
\mathrm{R}^{2}: \text { between } \\
\mathrm{R}^{2}: \text { overall }\end{array}$ & 0.4955 & & $\begin{array}{l}0.6868 \\
0.0911 \\
0.2861\end{array}$ & \\
\hline
\end{tabular}


Table 3a:

The Effect of Currency Unions on Trade: Does Size Matter?

1948 - 2006, Fixed Effects Estimator with Countrypair Fixed Effects.

\begin{tabular}{lc}
\hline \hline Dependent Variable: & Log of Bilateral Trade \\
\hline Currency Union & $2.661^{* *}$ \\
Currency Union x Log of Product of Real GDPs & $(1.092)$ \\
& $\mathbf{- 0 . 0 4 \mathbf { 1 } ^ { * }}$ \\
Free Trade Agreement & $\mathbf{( 0 . 0 2 1 )}$ \\
& 0.113 \\
Log of Product of Real GDPs & $(0.069)$ \\
& $-1.612^{* * *}$ \\
Log of Product of Real GDPs per capita & $(0.018)$ \\
\hline Currently in Colonial Relationship & $2.979 * * *$ \\
& $(0.024)$ \\
Real Exchange Rate of Country 1 & 1.032 \\
& $(0.815)$ \\
Real Exchange Rate of Country 2 & $0.068^{* * *}$ \\
& $(0.005)$ \\
Constant & $0.134 * * *$ \\
& $(0.012)$ \\
Observations & $32.558^{* * *}$ \\
Number of id & $(0.587)$ \\
R-squared & 168,174 \\
\hline \hline Standard errors in parentheses & 10,739 \\
$*$ significant at $10 \% ; * *$ significant at $5 \% ; * * *$ significant at $1 \%$ & 0.09 \\
\hline
\end{tabular}

Table 3b

The Effect of Currency Unions on Trade: Does Size Matter?

1948 - 2006, Fixed Effects Estimator with Countrypair and Year Fixed Effects.

\begin{tabular}{lc}
\hline \hline Dependent Variable: & Log of Bilateral Trade \\
\hline Currency Union & $1.887^{*}$ \\
Currency Union x Log of Product of Real GDPs & $(1.064)$ \\
Free Trade Agreement & $\mathbf{- 0 . 0 2 1}$ \\
& $(\mathbf{0 . 0 2 1 )}$ \\
Log of Product of Real GDPs & $0.436^{* * *}$ \\
& $(0.068)$ \\
Log of Product of Real GDPs per capita & $0.127^{* * *}$ \\
& $(0.044)$ \\
Currently in Colonial Relationship & $1.484^{* * *}$ \\
Real Exchange Rate of Country 1 & $(0.042)$ \\
& 0.811 \\
Real Exchange Rate of Country 2 & $(0.794)$ \\
& $-0.029^{* * *}$ \\
Constant & $(0.005)$ \\
Observations & $0.073^{* * *}$ \\
Number of id & $(0.012)$ \\
R-squared & $-28.055^{* * *}$ \\
\hline \hline
\end{tabular}

Standard errors in parentheses

* significant at $10 \%$;* significant at $5 \%$; *** significant at $1 \%$ 
Imbedding euro-based samples (with estimated impact on bilateral trade of 15\%) within larger sample (with much higher estimates): Step-by-step breakdown of possible sources of gap

Step 1: Recreate Micco, Stein \& Ordonez (2003) starting in 1992 (as they do) - both with EMU Dummy only and with EMU - Time Interactions, Using our Full Sample, as well as the Developed Sample and EU Sample that MSO use.

5A. Just With EMU Dummy, no EMU-Time Interactions

The Effect of Currency Unions on Trade: Recreating Micco, Stein \& Ordonez (2003) With Our Data (1992-2006)

1992 - 2006, Fixed Effects Estimator with Countrypair and Year Fixed Effects, as well as OLS Estimator with Year Fixed Effects.

\begin{tabular}{|c|c|c|c|c|c|c|}
\hline \multirow{2}{*}{$\begin{array}{l}\text { Dependent Variable: } \\
\text { Log of Bilateral Trade }\end{array}$} & \multicolumn{2}{|c|}{ Full Sample } & \multicolumn{2}{|c|}{ Developed Sample } & \multicolumn{2}{|c|}{ EU Sample } \\
\hline & Fixed Effects & OLS & Fixed Effects & OLS & Fixed Effects & OLS \\
\hline Both Countries in Non-EMU Currency Union & $\begin{array}{r}0.575 \\
(0.226)^{*}\end{array}$ & $\begin{array}{r}0.752 \\
(0.214)^{* *}\end{array}$ & (dropped) & (dropped) & (dropped) & (dropped) \\
\hline Both Countries in EMU & $\begin{array}{r}0.058 \\
(0.100)\end{array}$ & $\begin{array}{r}-0.017 \\
(0.130)\end{array}$ & $\begin{array}{r}0.06 \\
(0.018) * *\end{array}$ & $\begin{array}{r}-0.014 \\
(0.095)\end{array}$ & $\begin{array}{r}0.122 \\
(0.014)^{* *}\end{array}$ & $\begin{array}{r}0.301 \\
(0.078)^{* *}\end{array}$ \\
\hline Free Trade Agreement (Non-EU) & $\begin{array}{r}0.155 \\
(0.108)\end{array}$ & $\begin{array}{r}1.116 \\
(0.153) * *\end{array}$ & $\begin{array}{r}0.046 \\
(0.026)\end{array}$ & $\begin{array}{r}0.013 \\
(0.172)\end{array}$ & & \\
\hline Both Countries in EU & & $\begin{array}{r}-0.104 \\
(0.120)\end{array}$ & & $\begin{array}{r}0.344 \\
(0.125)^{* *}\end{array}$ & & \\
\hline European Integration Trend & $\begin{array}{r}0.007 \\
(0.008) \\
\end{array}$ & $\begin{array}{r}0.042 \\
(0.007) * * \\
\end{array}$ & $\begin{array}{r}0.001 \\
(0.001) \\
\end{array}$ & $\begin{array}{r}-0.003 \\
(0.005) \\
\end{array}$ & $\begin{array}{r}0.005 \\
(0.002)^{*} \\
\end{array}$ & $\begin{array}{r}0.011 \\
(0.005)^{*} \\
\end{array}$ \\
\hline Log of Distance & & $\begin{array}{r}-1.292 \\
(0.023)^{* *}\end{array}$ & & $\begin{array}{r}-0.856 \\
(0.071)^{* *}\end{array}$ & & $\begin{array}{r}-1.125 \\
(0.129)^{* *}\end{array}$ \\
\hline Log of Product of Real GDPs & $\begin{array}{r}1.206 \\
(0.019) * *\end{array}$ & $\begin{array}{r}1.033 \\
(0.012)^{* *}\end{array}$ & $\begin{array}{r}0.648 \\
(0.038)^{* *}\end{array}$ & $\begin{array}{r}0.774 \\
(0.026)^{* *}\end{array}$ & $\begin{array}{r}0.399 \\
(0.036)^{* *}\end{array}$ & $\begin{array}{r}0.667 \\
(0.049)^{* *}\end{array}$ \\
\hline Log of Product of Real GDPs per capita & & $\begin{array}{r}-0.057 \\
(0.014)^{* *}\end{array}$ & & $\begin{array}{r}0.38 \\
(0.103) * *\end{array}$ & & $\begin{array}{r}0.362 \\
(0.121)^{* *}\end{array}$ \\
\hline Common Language & & $\begin{array}{r}0.41 \\
(0.049) * * \\
\end{array}$ & & $\begin{array}{r}0.069 \\
(0.161) \\
\end{array}$ & & $\begin{array}{r}-0.155 \\
(0.255) \\
\end{array}$ \\
\hline Common Border & & $\begin{array}{r}0.789 \\
(0.117)^{* *}\end{array}$ & & $\begin{array}{r}0.316 \\
(0.161)\end{array}$ & & $\begin{array}{l}-0.036 \\
(0.147)\end{array}$ \\
\hline Number of Landlocked Countries in Pair & & $\begin{array}{r}-0.369 \\
(0.034)^{* *}\end{array}$ & & $\begin{array}{r}-0.382 \\
(0.100) * *\end{array}$ & & $\begin{array}{r}-0.657 \\
(0.115)^{* *}\end{array}$ \\
\hline Log of Product of Land Areas & & $\begin{array}{r}-0.08 \\
(0.009)^{* *}\end{array}$ & & $\begin{array}{r}0.018 \\
(0.030)\end{array}$ & & $\begin{array}{r}0.13 \\
(0.055)^{*}\end{array}$ \\
\hline Common Colonizer Post 1945 & & $\begin{array}{r}0.855 \\
(0.079)^{* *} \\
\end{array}$ & & & & \\
\hline Current Colony & & $\begin{array}{r}1.21 \\
(0.552)^{*}\end{array}$ & & & & \\
\hline Ever Colony & & $\begin{array}{r}1.218 \\
(0.132)^{* *}\end{array}$ & & $\begin{array}{r}0.521 \\
(0.219)^{*}\end{array}$ & & $\begin{array}{r}0.725 \\
(0.206)^{* *}\end{array}$ \\
\hline Real Exchange Rate of Country 1 & $\begin{array}{r}0.034 \\
(0.004)^{* *}\end{array}$ & $\begin{array}{r}-0.003 \\
(0.006)\end{array}$ & $\begin{array}{r}-0.019 \\
(0.003)^{* *}\end{array}$ & $\begin{array}{l}-0.048 \\
(0.021)^{*}\end{array}$ & $\begin{array}{r}0.001 \\
(0.003)\end{array}$ & $\begin{array}{r}0.005 \\
(0.017)\end{array}$ \\
\hline Real Exchange Rate of Country 2 & $\begin{array}{r}-0.038 \\
(0.012)^{* *} \\
\end{array}$ & $\begin{array}{r}-0.006 \\
(0.005) \\
\end{array}$ & $\begin{array}{r}0.002 \\
(0.003) \\
\end{array}$ & $\begin{array}{r}-0.064 \\
(0.017) * * \\
\end{array}$ & $\begin{array}{r}0.014 \\
(0.003) * * \\
\end{array}$ & $\begin{array}{r}0.005 \\
(0.014) \\
\end{array}$ \\
\hline Constant & $\begin{array}{r}-55.992 \\
(0.901)^{* *}\end{array}$ & $\begin{array}{r}-34.46 \\
(0.393)^{* *}\end{array}$ & $\begin{array}{r}-27.1 \\
(2.018)^{* *}\end{array}$ & $\begin{array}{r}-35.659 \\
(2.048) * *\end{array}$ & $\begin{array}{r}-13.113 \\
(1.905) * *\end{array}$ & $\begin{array}{r}-29.645 \\
(2.643)^{* *}\end{array}$ \\
\hline $\begin{array}{l}\text { Observations } \\
\text { Number of id }\end{array}$ & $\begin{array}{r}101,128 \\
9,576\end{array}$ & 100,747 & $\begin{array}{r}2,850 \\
190\end{array}$ & 2,850 & $\begin{array}{r}1,104 \\
78\end{array}$ & 1,104 \\
\hline R-squared & 0.09 & 0.69 & 0.55 & 0.92 & 0.77 & 0.95 \\
\hline
\end{tabular}

Standard errors in parentheses

* significant at $5 \%$; ** significant at $1 \%$ 
The following graph illustrates the results from the above table:

The Effect of EMU on Trade: Different Estimators and Samples (1992-2006)

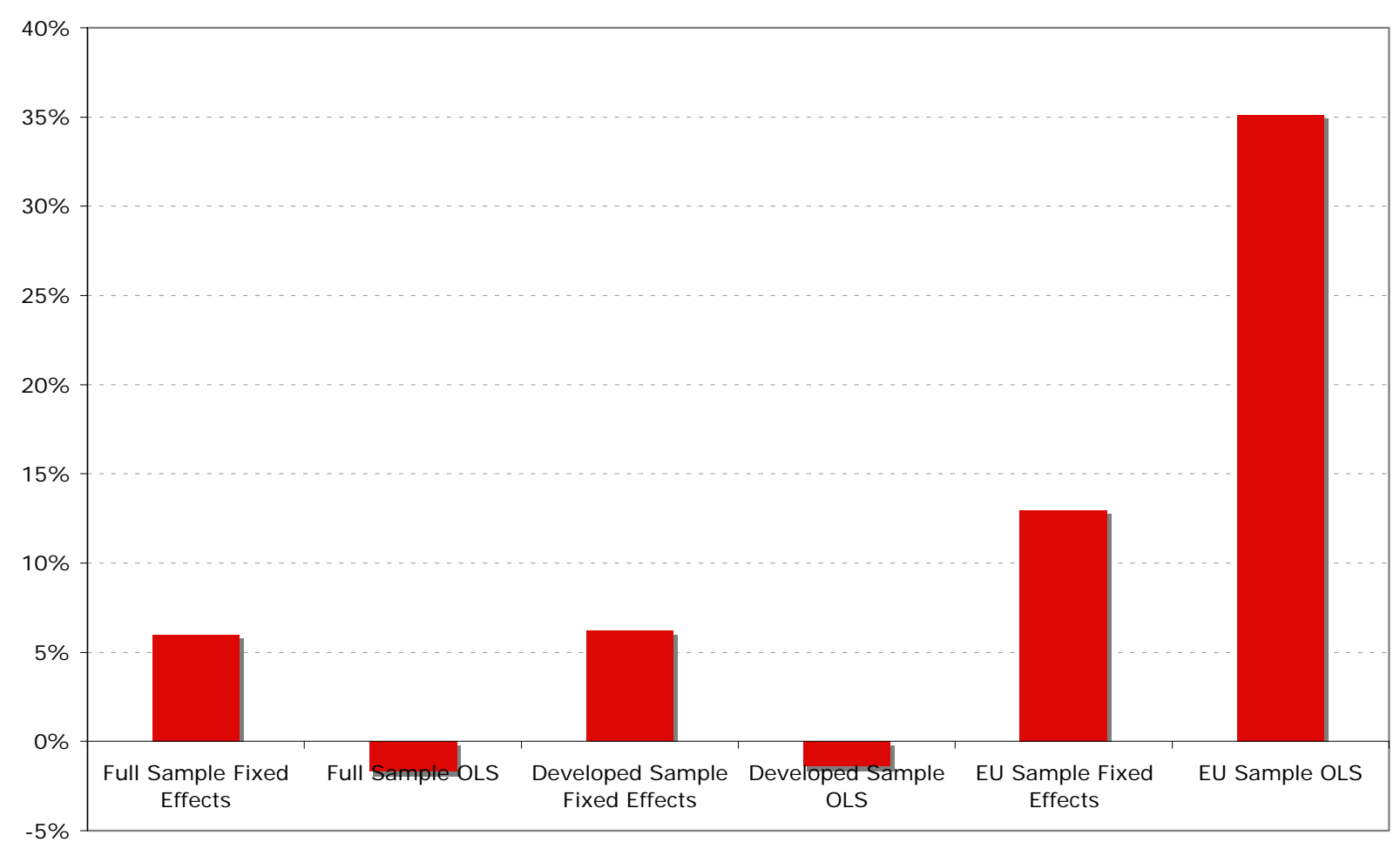


5B: Step 1 including EMU - Time Interactions (1992-2006 Sample Period):

The Effect of Currency Unions on Trade: Recreating Micco, Stein \& Ordonez (2003) With Our Data (1992-2006)

1992 - 2006, Fixed Effects Estimator with Countrypair and Year Fixed Effects, as well as OLS Estimator with Year Fixed Effects

\begin{tabular}{|c|c|c|c|c|c|c|}
\hline \multirow{2}{*}{$\begin{array}{l}\text { Dependent Variable: } \\
\text { Log of Bilateral Trade }\end{array}$} & \multicolumn{2}{|c|}{ Full Sample } & \multicolumn{2}{|c|}{ Developed Sample } & \multicolumn{2}{|c|}{ EU Sample } \\
\hline & Fixed Effects & $\mathrm{OLS}$ & Fixed Effects & $\mathrm{OLS}$ & Fixed Effects & OLS \\
\hline EMU * 1993 & $\begin{array}{r}-0.105 \\
(0.227)\end{array}$ & $\begin{array}{r}-0.192 \\
(0.047)^{* *}\end{array}$ & $\begin{array}{r}-0.037 \\
(0.041)\end{array}$ & $\begin{array}{r}-0.05 \\
(0.029)\end{array}$ & $\begin{array}{r}-0.019 \\
(0.047)\end{array}$ & $\begin{array}{r}-0.033 \\
(0.039)\end{array}$ \\
\hline EMU * 1994 & $\begin{array}{r}-0.196 \\
(0.245)\end{array}$ & $\begin{array}{r}-0.215 \\
(0.098)^{*}\end{array}$ & $\begin{array}{l}-0.032 \\
(0.042)\end{array}$ & $\begin{array}{r}-0.138 \\
(0.053)^{* *}\end{array}$ & $\begin{array}{r}-0.005 \\
(0.042)\end{array}$ & $\begin{array}{r}-0.182 \\
(0.074)^{*}\end{array}$ \\
\hline EMU * 1995 & $\begin{array}{r}-0.093 \\
(0.237)\end{array}$ & $\begin{array}{r}-0.026 \\
(0.102)\end{array}$ & $\begin{array}{l}-0.027 \\
(0.042)\end{array}$ & $\begin{array}{r}-0.144 \\
(0.052)^{* *}\end{array}$ & $\begin{array}{r}-0.014 \\
(0.042)\end{array}$ & $\begin{array}{r}-0.203 \\
(0.080)^{*}\end{array}$ \\
\hline EMU * 1996 & $\begin{array}{r}-0.104 \\
(0.242)\end{array}$ & $\begin{array}{r}-0.064 \\
(0.106)\end{array}$ & $\begin{array}{r}-0.037 \\
(0.042)\end{array}$ & $\begin{array}{r}-0.153 \\
(0.055)^{* *}\end{array}$ & $\begin{array}{r}-0.026 \\
(0.042)\end{array}$ & $\begin{array}{r}-0.211 \\
(0.079) * *\end{array}$ \\
\hline$\overline{E M U} * 1997$ & $\begin{array}{r}0.144 \\
(0.246)\end{array}$ & $\begin{array}{r}0.144 \\
(0.109)\end{array}$ & $\begin{array}{r}-0.021 \\
(0.042)\end{array}$ & $\begin{array}{r}-0.132 \\
(0.057)^{*}\end{array}$ & $\begin{array}{r}-0.007 \\
(0.042)\end{array}$ & $\begin{array}{r}-0.182 \\
(0.076)^{*}\end{array}$ \\
\hline EMU * 1998 & $\begin{array}{r}0.166 \\
(0.254)\end{array}$ & $\begin{array}{r}0.104 \\
(0.122)\end{array}$ & $\begin{array}{r}0.034 \\
(0.043)\end{array}$ & $\begin{array}{r}-0.087 \\
(0.064)\end{array}$ & $\begin{array}{r}0.046 \\
(0.042)\end{array}$ & $\begin{array}{r}-0.133 \\
(0.078)\end{array}$ \\
\hline EMU * 1999 & $\begin{array}{r}0.212 \\
(0.254)\end{array}$ & $\begin{array}{r}0.195 \\
(0.123)\end{array}$ & $\begin{array}{r}0.034 \\
(0.043)\end{array}$ & $\begin{array}{r}-0.221 \\
(0.078)^{* *}\end{array}$ & $\begin{array}{r}0.072 \\
(0.043)\end{array}$ & $\begin{array}{r}-0.119 \\
(0.085)\end{array}$ \\
\hline $\mathrm{EMU} * 2000$ & $\begin{array}{r}0.163 \\
(0.256) \\
\end{array}$ & $\begin{array}{r}0.146 \\
(0.122)\end{array}$ & $\begin{array}{r}0.013 \\
(0.044)\end{array}$ & $\begin{array}{r}-0.244 \\
(0.080)^{* *}\end{array}$ & $\begin{array}{r}0.078 \\
(0.043)\end{array}$ & $\begin{array}{r}-0.116 \\
(0.085)\end{array}$ \\
\hline$\overline{\mathrm{EMU} * 2001}$ & 0.046 & 0.077 & 0.078 & -0.304 & 0.171 & -0.049 \\
\hline & $(0.261)$ & $(0.127)$ & $(0.044)$ & $(0.089) * *$ & $(0.043) * *$ & $(0.086)$ \\
\hline EMU * 2002 & $\begin{array}{r}-0.002 \\
(0.261)\end{array}$ & $\begin{array}{r}0.045 \\
(0.131)\end{array}$ & $\begin{array}{r}0.058 \\
(0.044)\end{array}$ & $\begin{array}{r}-0.329 \\
(0.091)^{* *}\end{array}$ & $\begin{array}{r}0.147 \\
(0.043)^{* *}\end{array}$ & $\begin{array}{r}-0.072 \\
(0.091)\end{array}$ \\
\hline EMU * 2003 & $\begin{array}{r}0.112 \\
(0.260)\end{array}$ & $\begin{array}{r}0.175 \\
(0.133)\end{array}$ & $\begin{array}{r}0.12 \\
(0.044)^{* *}\end{array}$ & $\begin{array}{r}-0.27 \\
(0.093)^{* *}\end{array}$ & $\begin{array}{r}0.17 \\
(0.043)^{* *}\end{array}$ & $\begin{array}{r}-0.047 \\
(0.092)\end{array}$ \\
\hline EMU * 2004 & $\begin{array}{r}0.105 \\
(0.258) \\
\end{array}$ & $\begin{array}{r}0.21 \\
(0.131) \\
\end{array}$ & $\begin{array}{r}0.121 \\
(0.044)^{* *} \\
\end{array}$ & $\begin{array}{r}-0.266 \\
(0.094) * * \\
\end{array}$ & $\begin{array}{r}0.176 \\
(0.043)^{* *} \\
\end{array}$ & $\begin{array}{r}-0.038 \\
(0.095) \\
\end{array}$ \\
\hline$\overline{E M U} * 2005$ & $\begin{array}{r}-0.036 \\
(0.262)\end{array}$ & $\begin{array}{r}0.016 \\
(0.135)\end{array}$ & $\begin{array}{r}0.051 \\
(0.044)\end{array}$ & $\begin{array}{r}-0.331 \\
(0.099)^{* *}\end{array}$ & $\begin{array}{r}0.13 \\
(0.043)^{* *}\end{array}$ & $\begin{array}{r}-0.079 \\
(0.095)\end{array}$ \\
\hline EMU * 2006 & $\begin{array}{r}-0.118 \\
(0.262)\end{array}$ & $\begin{array}{r}-0.08 \\
(0.136)\end{array}$ & $\begin{array}{r}0.028 \\
(0.044)\end{array}$ & $\begin{array}{r}-0.359 \\
(0.102)^{* *}\end{array}$ & $\begin{array}{r}0.102 \\
(0.043)^{*}\end{array}$ & $\begin{array}{r}-0.107 \\
(0.100)\end{array}$ \\
\hline Both Countries in Non-EMU Currency Union & $\begin{array}{r}0.576 \\
(0.226)^{*}\end{array}$ & $\begin{array}{r}0.752 \\
(0.214)^{* *}\end{array}$ & & & & \\
\hline Both Countries in EMU & & $\begin{array}{r}-0.177 \\
(0.155) \\
\end{array}$ & & $\begin{array}{r}0.273 \\
(0.101)^{* *} \\
\end{array}$ & & $\begin{array}{r}0.354 \\
(0.109)^{* *} \\
\end{array}$ \\
\hline Free Trade Agreement (Non-EU) & $\begin{array}{r}0.166 \\
(0.108)\end{array}$ & $\begin{array}{r}1.117 \\
(0.153)^{* *}\end{array}$ & $\begin{array}{r}0.051 \\
(0.027)\end{array}$ & $\begin{array}{r}0.026 \\
(0.172)\end{array}$ & & \\
\hline Both Countries in EU & $\begin{array}{r}0.209 \\
(0.183)\end{array}$ & $\begin{array}{r}-0.069 \\
(0.146)\end{array}$ & $\begin{array}{r}0.014 \\
(0.031)\end{array}$ & $\begin{array}{r}0.361 \\
(0.131)^{* *}\end{array}$ & & \\
\hline European Integration Trend & $\begin{array}{r}0.008 \\
(0.010)\end{array}$ & $\begin{array}{r}0.035 \\
(0.008)^{* *}\end{array}$ & $\begin{array}{r}0 \\
(0.002)\end{array}$ & $\begin{array}{r}0.003 \\
(0.005)\end{array}$ & $\begin{array}{r}0.005 \\
(0.002) *\end{array}$ & $\begin{array}{r}0.011 \\
(0.004)^{*}\end{array}$ \\
\hline Log of Distance & & $\begin{array}{r}-1.292 \\
(0.023) * * \\
\end{array}$ & & $\begin{array}{r}-0.845 \\
(0.071) * * \\
\end{array}$ & & $\begin{array}{r}-1.112 \\
(0.135)^{* *} \\
\end{array}$ \\
\hline Log of Product of Real GDPs & $\begin{array}{r}1.205 \\
(0.019)^{* *}\end{array}$ & $\begin{array}{r}1.033 \\
(0.012)^{* *}\end{array}$ & $\begin{array}{r}0.645 \\
(0.038) * *\end{array}$ & $\begin{array}{r}0.774 \\
(0.026)^{* *}\end{array}$ & $\begin{array}{r}0.412 \\
(0.036)^{* *}\end{array}$ & $\begin{array}{r}0.669 \\
(0.051)^{* *}\end{array}$ \\
\hline Log of Product of Real GDPs per capita & & $\begin{array}{r}-0.057 \\
(0.014)^{* *}\end{array}$ & & $\begin{array}{r}0.407 \\
(0.104) * *\end{array}$ & & $\begin{array}{r}0.39 \\
(0.121)^{* *}\end{array}$ \\
\hline Common Language & & $\begin{array}{r}0.409 \\
(0.050)^{* *}\end{array}$ & & $\begin{array}{r}0.076 \\
(0.161)\end{array}$ & & $\begin{array}{r}-0.118 \\
(0.259)\end{array}$ \\
\hline Common Border & & $\begin{array}{r}0.79 \\
(0.117) * *\end{array}$ & & $\begin{array}{r}0.32 \\
(0.161)^{*}\end{array}$ & & $\begin{array}{r}-0.04 \\
(0.150)\end{array}$ \\
\hline Number of Landlocked Countries in Pair & & $\begin{array}{r}-0.369 \\
(0.034) * *\end{array}$ & & $\begin{array}{r}-0.397 \\
(0.101)^{* *}\end{array}$ & & $\begin{array}{r}-0.668 \\
(0.117)^{* *}\end{array}$ \\
\hline Log of Product of Land Areas & & $\begin{array}{r}-0.08 \\
(0.009)^{* *}\end{array}$ & & $\begin{array}{r}0.015 \\
(0.030)\end{array}$ & & $\begin{array}{r}0.129 \\
(0.056)^{*}\end{array}$ \\
\hline Common Colonizer Post 1945 & & $\begin{array}{r}0.855 \\
(0.079)^{* *}\end{array}$ & & & & \\
\hline Current Colony & & $\begin{array}{r}1.21 \\
(0.553)^{*}\end{array}$ & & & & \\
\hline Ever Colony & & $\begin{array}{r}1.219 \\
(0.132)^{* *}\end{array}$ & & $\begin{array}{r}0.507 \\
(0.220)^{*}\end{array}$ & & $\begin{array}{r}0.701 \\
(0.205)^{* *}\end{array}$ \\
\hline Real Exchange Rate of Country 1 & $\begin{array}{r}0.034 \\
(0.004)^{* *}\end{array}$ & $\begin{array}{r}-0.003 \\
(0.006)\end{array}$ & $\begin{array}{r}-0.018 \\
(0.003) * *\end{array}$ & $\begin{array}{r}-0.051 \\
(0.021)^{*}\end{array}$ & $\begin{array}{r}0.001 \\
(0.003)\end{array}$ & $\begin{array}{r}-0.001 \\
(0.016)\end{array}$ \\
\hline Real Exchange Rate of Country 2 & $\begin{array}{r}-0.037 \\
(0.013)^{* *}\end{array}$ & $\begin{array}{r}-0.006 \\
(0.005)\end{array}$ & $\begin{array}{r}0.004 \\
(0.003)\end{array}$ & $\begin{array}{r}-0.071 \\
(0.017)^{* *}\end{array}$ & $\begin{array}{r}0.013 \\
(0.003)^{* *}\end{array}$ & $\begin{array}{r}-0.007 \\
(0.014)\end{array}$ \\
\hline Constant & $\begin{array}{r}-55.96 \\
(0.901)^{* *} \\
\end{array}$ & $\begin{array}{r}-34.464 \\
(0.393) * * \\
\end{array}$ & $\begin{array}{r}-26.966 \\
(2.009) * * \\
\end{array}$ & $\begin{array}{r}-36.249 \\
(2.114)^{* *} \\
\end{array}$ & $\begin{array}{r}-13.838 \\
(1.880) * * \\
\end{array}$ & $\begin{array}{r}-30.58 \\
(2.724)^{* *} \\
\end{array}$ \\
\hline Observations & 101,128 & 100,747 & 2,850 & 2,850 & 1,104 & 1,104 \\
\hline Number of id & 9,576 & & 190 & & 78 & \\
\hline R-squared & 0.09 & 0.69 & 0.56 & 0.92 & 0.78 & 0.95 \\
\hline
\end{tabular}

Standard errors in parentheses

* significant at $5 \%$; ** significant at $1 \%$ 
The following two graphs illustrate the results from the above table (the first one for the fixed effects estimates and the second one for the OLS estimates:

The Effect of EMU on Bilateral Trade: Recreating Micco, Stein \& Ordonez (2003) with our Data: Fixed Effects Estimators

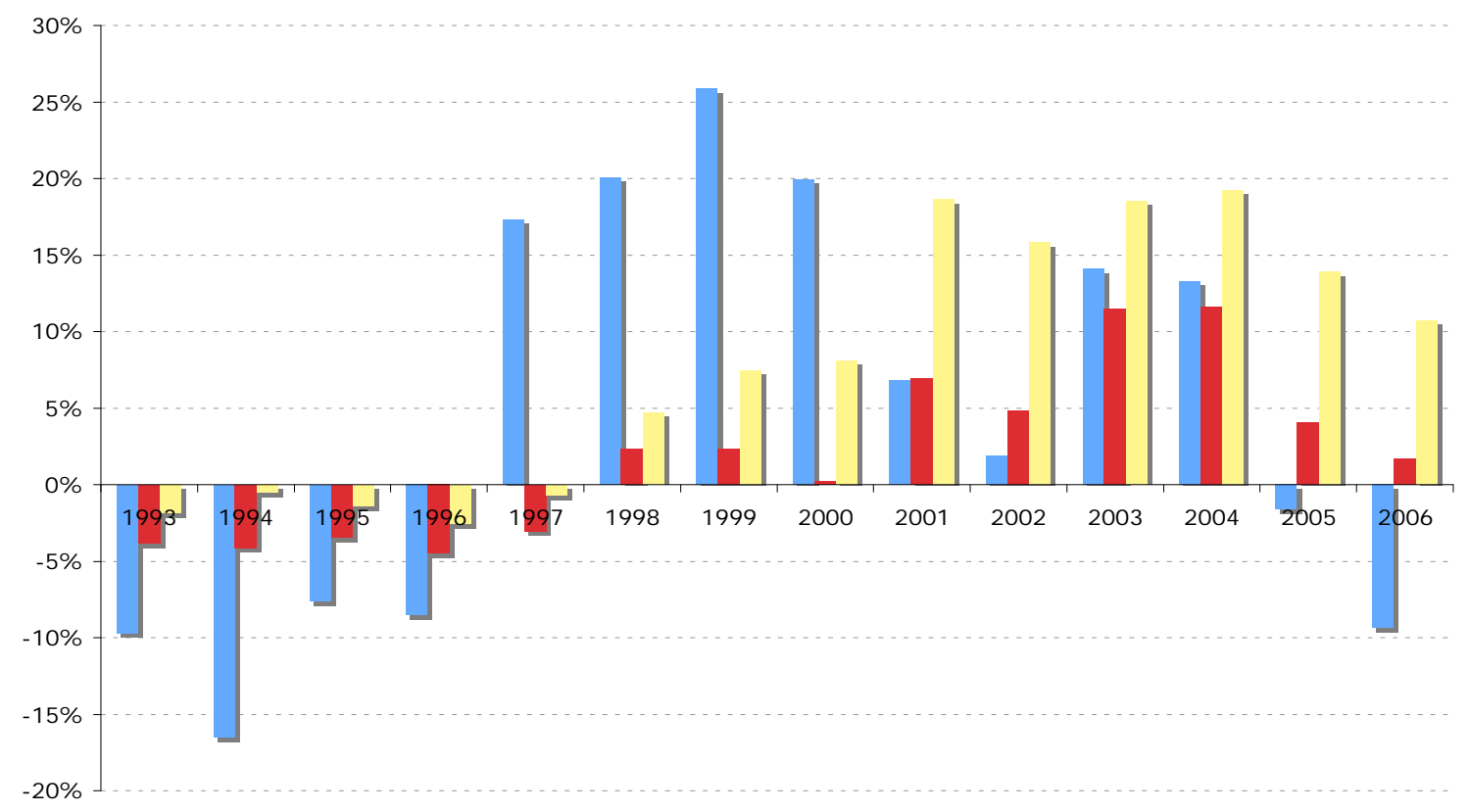

Full Sample Fixed Effects Developed Sample Fixed Effects EU Sample Fixed Effects

The Effect of EMU on Bilateral Trade: Recreating Micco, Stein \& Ordonez (2003) with our Data: OLS Estimators

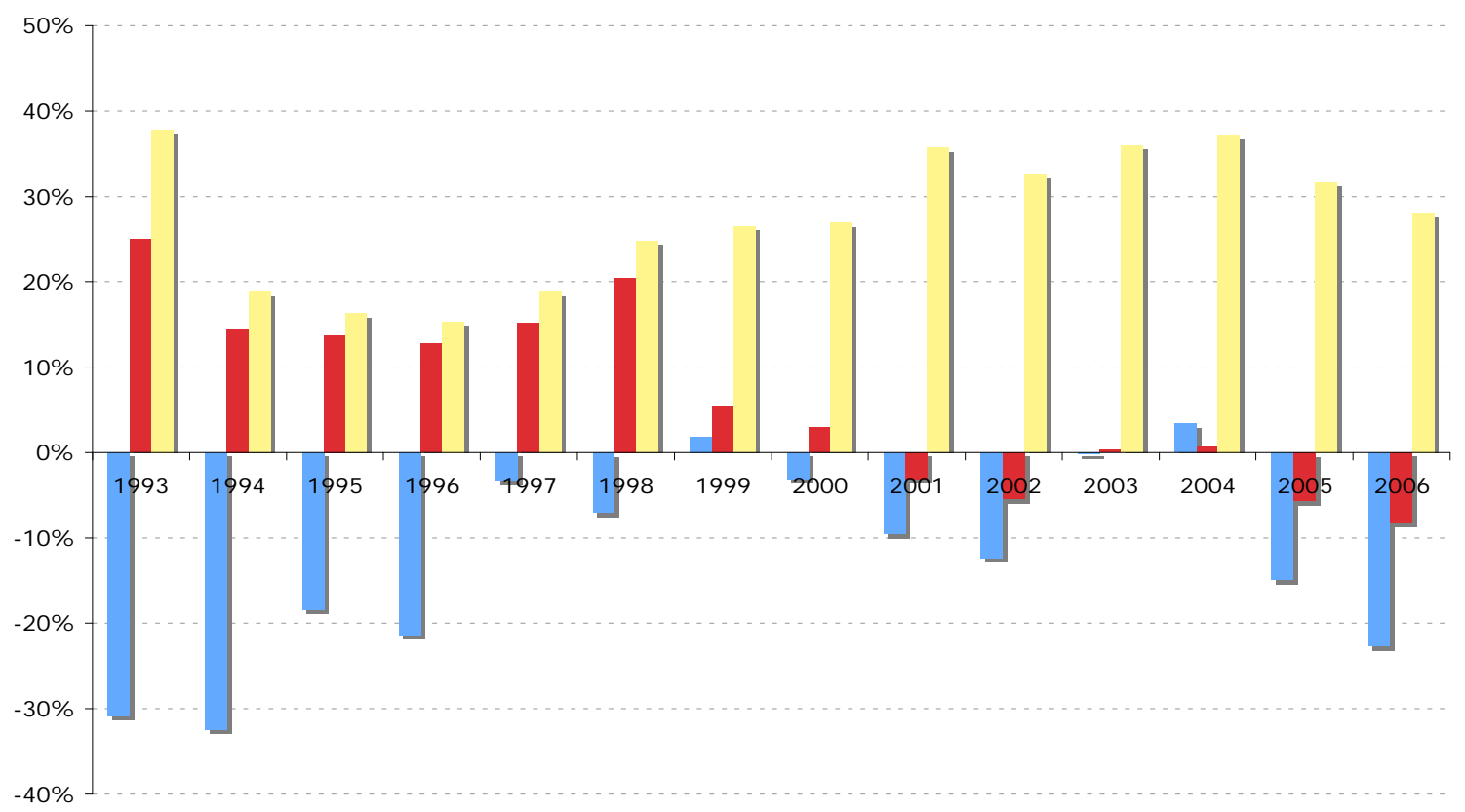

Full Sample OLS Developed Sample OLS EU Sample OLS 
Step 2: Expand the sample period to 1948-2006.

\section{A.: Just with EMU Dummy, no EMU - Time Interactions}

The Effect of Currency Unions on Trade: Full Data from 1948 with EMU Dummy

1948 - 2006, Fixed Effects Estimator with Countrypair and Year Fixed Effects, as well as OLS Estimator with Year Fixed Effects

\begin{tabular}{|c|c|c|c|c|c|c|}
\hline \multirow{2}{*}{$\begin{array}{l}\text { Dependent Variable: } \\
\text { Log of Bilateral Trade }\end{array}$} & \multicolumn{2}{|c|}{ Full Sample } & \multicolumn{2}{|c|}{ "Developed Sample } & \multicolumn{2}{|c|}{ EU Sample } \\
\hline & Fixed Effects & $\overline{\mathrm{OLS}}$ & Fixed Effects & $\mathrm{OLS}$ & Fixed Effects & $\overline{\mathrm{OLS}}$ \\
\hline Both Countries in Non-EMU Currency Union & $\begin{array}{r}0.746 \\
(0.188)^{* *}\end{array}$ & $\begin{array}{r}0.309 \\
(0.244)\end{array}$ & (dropped) & (dropped) & (dropped) & (dropped) \\
\hline Both Countries in EMU & $\begin{array}{r}0.93 \\
(0.116) * *\end{array}$ & $\begin{array}{r}1.005 \\
(0.097) * *\end{array}$ & $\begin{array}{r}0.097 \\
(0.014) * *\end{array}$ & $\begin{array}{r}-0.076 \\
(0.094)\end{array}$ & $\begin{array}{r}0.12 \\
(0.013)^{* *}\end{array}$ & $\begin{array}{r}0.241 \\
(0.077)^{* *}\end{array}$ \\
\hline Free Trade Agreement (Non-EU) & $\begin{array}{r}0.662 \\
(0.085)^{* *}\end{array}$ & $\begin{array}{r}0.794 \\
(0.184)^{* *}\end{array}$ & $\begin{array}{r}0.057 \\
(0.012)^{* *}\end{array}$ & $\begin{array}{r}0.097 \\
(0.117)\end{array}$ & & \\
\hline Both Countries in EU & & $\begin{array}{r}0.042 \\
(0.096)\end{array}$ & & $\begin{array}{r}0.187 \\
(0.076)^{*}\end{array}$ & & \\
\hline European Integration Trend & $\begin{array}{r}-0.005 \\
(0.009) \\
\end{array}$ & $\begin{array}{r}0.009 \\
(0.003) * * \\
\end{array}$ & $\begin{array}{r}-0.005 \\
(0.001) * * \\
\end{array}$ & $\begin{array}{r}-0.005 \\
(0.002)^{*} \\
\end{array}$ & $\begin{array}{r}0.001 \\
(0.001) \\
\end{array}$ & $\begin{array}{r}0.006 \\
(0.003) \\
\end{array}$ \\
\hline Log of Distance & & $\begin{array}{r}-1.043 \\
(0.032) * *\end{array}$ & & $\begin{array}{r}-0.861 \\
(0.061)^{* *}\end{array}$ & & $\begin{array}{r}-1.105 \\
(0.123)^{* *}\end{array}$ \\
\hline Log of Product of Real GDPs & $\begin{array}{r}1.592 \\
(0.015)^{* *}\end{array}$ & $\begin{array}{r}0.819 \\
(0.015)^{* *}\end{array}$ & $\begin{array}{r}0.513 \\
(0.020)^{* *}\end{array}$ & $\begin{array}{r}0.795 \\
(0.025)^{* *}\end{array}$ & $\begin{array}{r}0.376 \\
(0.024)^{* *}\end{array}$ & $\begin{array}{r}0.678 \\
(0.050)^{* *}\end{array}$ \\
\hline Log of Product of Real GDPs per capita & & $\begin{array}{r}-0.009 \\
(0.018)\end{array}$ & & $\begin{array}{r}0.164 \\
(0.094)\end{array}$ & & $\begin{array}{r}0.248 \\
(0.132)\end{array}$ \\
\hline Common Language & & $\begin{array}{r}0.296 \\
(0.067) * * \\
\end{array}$ & & $\begin{array}{r}0.011 \\
(0.152) \\
\end{array}$ & & $\begin{array}{r}-0.181 \\
(0.235) \\
\end{array}$ \\
\hline Common Border & & $\begin{array}{r}0.664 \\
(0.139) * *\end{array}$ & & $\begin{array}{r}0.337 \\
(0.148)^{*}\end{array}$ & & $\begin{array}{r}0.015 \\
(0.130)\end{array}$ \\
\hline Number of Landlocked Countries in Pair & & $\begin{array}{r}-0.391 \\
(0.046)^{* *}\end{array}$ & & $\begin{array}{r}-0.448 \\
(0.088) * *\end{array}$ & & $\begin{array}{r}-0.64 \\
(0.117)^{* *}\end{array}$ \\
\hline Log of Product of Land Areas & & $\begin{array}{r}-0.071 \\
(0.012) * *\end{array}$ & & $\begin{array}{r}-0.006 \\
(0.028)\end{array}$ & & $\begin{array}{r}0.119 \\
(0.056)^{*}\end{array}$ \\
\hline Common Colonizer Post 1945 & & $\begin{array}{r}0.678 \\
(0.098) * *\end{array}$ & & & & \\
\hline Current Colony & & $\begin{array}{r}-0.254 \\
(0.234)\end{array}$ & & & & \\
\hline Ever Colony & & $\begin{array}{r}1.023 \\
(0.142)^{* *}\end{array}$ & & $\begin{array}{r}0.529 \\
(0.222)^{*}\end{array}$ & & $\begin{array}{r}0.69 \\
(0.194)^{* *}\end{array}$ \\
\hline Same Nation & & $\begin{array}{r}0.457 \\
(0.626)\end{array}$ & & & & \\
\hline Real Exchange Rate of Country 1 & $\begin{array}{r}-0.071 \\
(0.005) * * \\
\end{array}$ & $\begin{array}{r}-0.006 \\
(0.008) \\
\end{array}$ & $\begin{array}{r}-0.028 \\
(0.002) * * \\
\end{array}$ & $\begin{array}{r}-0.065 \\
(0.023) * * \\
\end{array}$ & $\begin{array}{r}-0.007 \\
(0.003) * \\
\end{array}$ & $\begin{array}{r}-0.008 \\
(0.018) \\
\end{array}$ \\
\hline Real Exchange Rate of Country 2 & $\begin{array}{r}-0.018 \\
(0.012)\end{array}$ & $\begin{array}{r}-0.001 \\
(0.008)\end{array}$ & $\begin{array}{r}-0.005 \\
(0.002)^{*}\end{array}$ & $\begin{array}{r}-0.08 \\
(0.017)^{* *}\end{array}$ & $\begin{array}{r}0.011 \\
(0.002)^{* *}\end{array}$ & $\begin{array}{r}-0.016 \\
(0.014)\end{array}$ \\
\hline Constant & $\begin{array}{c}-72.821 \\
(0.713)^{* *}\end{array}$ & $\begin{array}{c}-25.903 \\
(0.499)^{* *}\end{array}$ & $\begin{array}{l}-19.917 \\
(1.050)^{* *}\end{array}$ & $\begin{array}{l}-32.311 \\
(1.750)^{* *}\end{array}$ & $\begin{array}{l}-11.718 \\
(1.264)^{* *}\end{array}$ & $\begin{array}{l}-28.14 \\
(2.465)^{* *}\end{array}$ \\
\hline $\begin{array}{l}\text { Observations } \\
\text { Number of id }\end{array}$ & $\begin{array}{r}166,990 \\
10,590\end{array}$ & 166,609 & $\begin{array}{r}5,130 \\
190\end{array}$ & 5,130 & $\begin{array}{r}1,601 \\
78\end{array}$ & 1,601 \\
\hline R-squared & 0.13 & 0.43 & 0.65 & 0.92 & 0.81 & 0.95 \\
\hline
\end{tabular}

Standard errors in parentheses

* significant at $5 \%$; ** significant at $1 \%$ 
The following graph illustrates the above results for the sample period 1948-2006:

The Effect of EMU on Trade: Different Estimators and Samples, 1948-2006

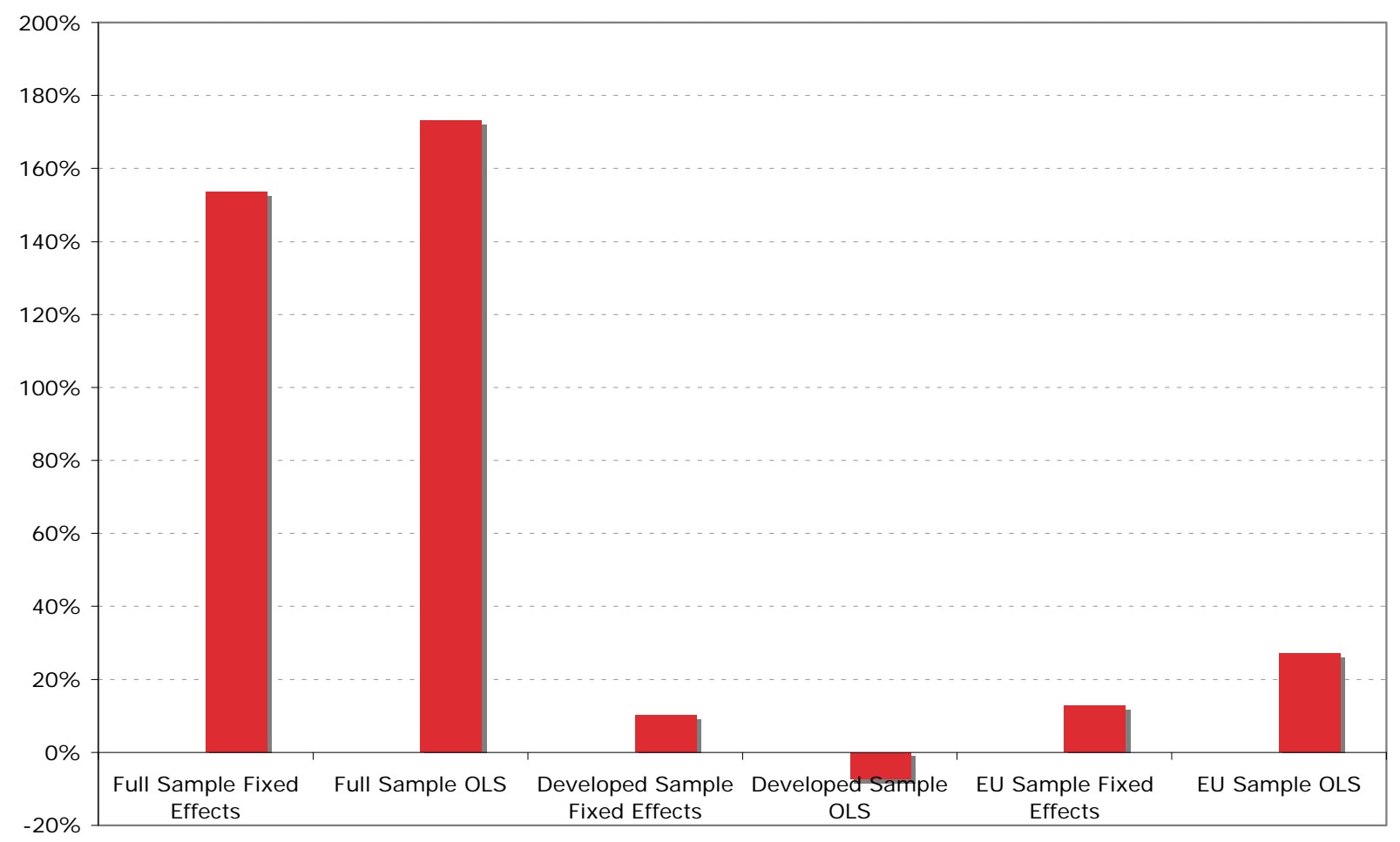


6B. Step 2 With Non-EMU Currency Unions and EMU-Time Interactions (1948-2006)

The Effect of Currency Unions on Trade: 1948-2006 Data and Currency Union and EMU - Time I nteractions

1948 - 2006, Fixed Effects Estimator with Countrypair and Year Fixed Effects, as well as OLS Estimator with Year Fixed Effects.

\begin{tabular}{|c|c|c|c|c|c|c|}
\hline \multirow{2}{*}{$\begin{array}{l}\text { Dependent Variable: } \\
\text { Log of Bilateral Trade }\end{array}$} & \multicolumn{2}{|c|}{ Full Sample } & \multicolumn{2}{|c|}{ Developed Sample } & \multicolumn{2}{|c|}{ EU Sample } \\
\hline & Fixed Effects & OLS & Fixed Effects & OLS & Fixed Effects & OLS \\
\hline 1 Year Prior to Non-EMU Currency Union Entry & $\begin{array}{r}1.102 \\
(1.228)\end{array}$ & $\begin{array}{r}1.823 \\
(0.160)^{* *}\end{array}$ & & & & \\
\hline 1-5 Years Post Non-EMU Currency Union Entry & $\begin{array}{r}0.849 \\
(0.444)\end{array}$ & $\begin{array}{r}2.36 \\
(0.917)^{*}\end{array}$ & & & & \\
\hline 6-10 Years Post Non-EMU Currency Union Entry & $\begin{array}{r}-0.048 \\
(0.397)\end{array}$ & $\begin{array}{r}0.713 \\
(1.010)\end{array}$ & & & & \\
\hline 11-15 Years Post Non-EMU Currency Union Entry & $\begin{array}{r}-1.049 \\
(0.381)^{* *} \\
\end{array}$ & $\begin{array}{r}0.388 \\
(0.843) \\
\end{array}$ & & & & \\
\hline 16-20 Years Post Non-EMU Currency Union Entry & $\begin{array}{r}-1.351 \\
(0.376) * *\end{array}$ & $\begin{array}{r}0.274 \\
(0.874)\end{array}$ & & & & \\
\hline 21-25 Years Post Non-EMU Currency Union Entry & $\begin{array}{r}-1.911 \\
(0.383)^{* *}\end{array}$ & $\begin{array}{r}-0.094 \\
(0.383)\end{array}$ & & & & \\
\hline 26-30 Years Post Non-EMU Currency Union Entry & $\begin{array}{r}-1.127 \\
(0.383) * *\end{array}$ & $\begin{array}{r}0.342 \\
(0.425)\end{array}$ & & & & \\
\hline 1 Year Prior to EMU Entry & $\begin{array}{r}0.563 \\
(0.234)^{*} \\
\end{array}$ & $\begin{array}{r}0.939 \\
(0.099) * * \\
\end{array}$ & $\begin{array}{r}0.074 \\
(0.025) * * \\
\end{array}$ & $\begin{array}{r}0.223 \\
(0.069) * * \\
\end{array}$ & $\begin{array}{r}0.052 \\
(0.023) * \\
\end{array}$ & $\begin{array}{r}0.23 \\
(0.071)^{* *} \\
\end{array}$ \\
\hline 1-5 Years Post EMU Entry & $\begin{array}{r}0.018 \\
(0.171)\end{array}$ & $\begin{array}{r}-0.024 \\
(0.032)\end{array}$ & $\begin{array}{r}-0.048 \\
(0.019) * *\end{array}$ & & $\begin{array}{r}-0.049 \\
(0.017) * *\end{array}$ & $\begin{array}{r}-0.176 \\
(0.049) * *\end{array}$ \\
\hline 6-10 Years Post EMU Entry & & & & $\begin{array}{r}0.181 \\
(0.042)^{* *}\end{array}$ & & \\
\hline Both Countries in Non-EMU Currency Union & $\begin{array}{r}0.907 \\
(0.197)^{* *}\end{array}$ & $\begin{array}{r}0.237 \\
(0.264)\end{array}$ & & & & \\
\hline Both Countries in EMU & $\begin{array}{r}0.767 \\
(0.167) * * \\
\end{array}$ & $\begin{array}{r}1.001 \\
(0.111) * * \\
\end{array}$ & $\begin{array}{r}0.115 \\
(0.019) * * \\
\end{array}$ & $\begin{array}{r}-0.08 \\
(0.101) \\
\end{array}$ & $\begin{array}{r}0.169 \\
(0.019) * * \\
\end{array}$ & $\begin{array}{r}0.451 \\
(0.097)^{* *} \\
\end{array}$ \\
\hline Free Trade Agreement (Non-EU) & $\begin{array}{r}0.485 \\
(0.082) * *\end{array}$ & $\begin{array}{r}0.735 \\
(0.182) * *\end{array}$ & $\begin{array}{r}0.078 \\
(0.012) * *\end{array}$ & $\begin{array}{r}0.1 \\
(0.108)\end{array}$ & & \\
\hline Both Countries in EU & $\begin{array}{r}0.451 \\
(0.116)^{* *}\end{array}$ & $\begin{array}{r}0.052 \\
(0.109)\end{array}$ & $\begin{array}{r}0.1 \\
(0.012)^{* *}\end{array}$ & $\begin{array}{r}0.13 \\
(0.081)\end{array}$ & & \\
\hline European Integration Trend & $\begin{array}{r}0.032 \\
(0.010)^{* *}\end{array}$ & $\begin{array}{r}0.012 \\
(0.004)^{* *}\end{array}$ & $\begin{array}{r}-0.002 \\
(0.001)\end{array}$ & $\begin{array}{r}-0.007 \\
(0.002)^{* *}\end{array}$ & $\begin{array}{r}0.012 \\
(0.002)^{* *}\end{array}$ & $\begin{array}{r}0.001 \\
(0.003)\end{array}$ \\
\hline Log of Distance & & $\begin{array}{r}-1.045 \\
(0.032)^{* *} \\
\end{array}$ & & $\begin{array}{r}-0.852 \\
(0.059)^{* *} \\
\end{array}$ & & $\begin{array}{r}-1.078 \\
(0.117)^{* *} \\
\end{array}$ \\
\hline Log of Product of Real GDPs & $\begin{array}{r}0.114 \\
(0.044)^{*}\end{array}$ & $\begin{array}{r}0.823 \\
(0.015)^{* *}\end{array}$ & $\begin{array}{r}0.525 \\
(0.019) * *\end{array}$ & $\begin{array}{r}0.801 \\
(0.025)^{* *}\end{array}$ & $\begin{array}{r}0.401 \\
(0.025)^{* *}\end{array}$ & $\begin{array}{r}0.699 \\
(0.046)^{* *}\end{array}$ \\
\hline Log of Product of Real GDPs per capita & $\begin{array}{r}1.5 \\
(0.042)^{* *}\end{array}$ & $\begin{array}{r}-0.011 \\
(0.018)\end{array}$ & & $\begin{array}{r}0.147 \\
(0.092)\end{array}$ & & $\begin{array}{r}0.256 \\
(0.132)\end{array}$ \\
\hline Common Language & & $\begin{array}{r}0.307 \\
(0.067)^{* *}\end{array}$ & & $\begin{array}{r}0.019 \\
(0.144)\end{array}$ & & $\begin{array}{r}-0.111 \\
(0.229)\end{array}$ \\
\hline Common Border & & $\begin{array}{r}0.655 \\
(0.138) * * \\
\end{array}$ & & $\begin{array}{r}0.348 \\
(0.145)^{*} \\
\end{array}$ & & $\begin{array}{r}0.052 \\
(0.135) \\
\end{array}$ \\
\hline Number of Landlocked Countries in Pair & & $\begin{array}{r}-0.393 \\
(0.046) * *\end{array}$ & & $\begin{array}{r}-0.494 \\
(0.084) * *\end{array}$ & & $\begin{array}{r}-0.709 \\
(0.115) * *\end{array}$ \\
\hline Log of Product of Land Areas & & $\begin{array}{r}-0.074 \\
(0.012)^{* *}\end{array}$ & & $\begin{array}{r}-0.022 \\
(0.027)\end{array}$ & & $\begin{array}{r}0.071 \\
(0.048)\end{array}$ \\
\hline Common Colonizer Post 1945 & & $\begin{array}{r}0.67 \\
(0.098)^{* *}\end{array}$ & & & & \\
\hline Current Colony & & $\begin{array}{r}-0.258 \\
(0.235) \\
\end{array}$ & & & & \\
\hline Ever Colony & & $\begin{array}{r}1.006 \\
(0.141)^{* *}\end{array}$ & & $\begin{array}{r}0.499 \\
(0.211)^{*}\end{array}$ & & $\begin{array}{r}0.595 \\
(0.170)^{* *}\end{array}$ \\
\hline Same Nation & & $\begin{array}{r}0.44 \\
(0.623)\end{array}$ & & & & \\
\hline Real Exchange Rate of Country 1 & $\begin{array}{r}-0.029 \\
(0.005)^{* *}\end{array}$ & $\begin{array}{r}-0.007 \\
(0.008)\end{array}$ & $\begin{array}{r}-0.027 \\
(0.002)^{* *}\end{array}$ & $\begin{array}{r}-0.069 \\
(0.023) * *\end{array}$ & $\begin{array}{r}-0.007 \\
(0.003)^{*}\end{array}$ & $\begin{array}{r}-0.003 \\
(0.017)\end{array}$ \\
\hline Real Exchange Rate of Country 2 & $\begin{array}{r}0.073 \\
(0.012)^{* *} \\
\end{array}$ & $\begin{array}{r}0 \\
(0.008) \\
\end{array}$ & $\begin{array}{r}-0.003 \\
(0.002) \\
\end{array}$ & $\begin{array}{r}-0.085 \\
(0.017) * * \\
\end{array}$ & $\begin{array}{r}0.012 \\
(0.003) * * \\
\end{array}$ & $\begin{array}{r}-0.008 \\
(0.015) \\
\end{array}$ \\
\hline Constant & $\begin{array}{r}-27.662 \\
(1.537)^{* *}\end{array}$ & $\begin{array}{r}-25.806 \\
(0.495)^{* *}\end{array}$ & $\begin{array}{r}-20.545 \\
(1.037)^{* *}\end{array}$ & $\begin{array}{r}-31.916 \\
(1.721)^{* *}\end{array}$ & $\begin{array}{r}-12.921 \\
(1.336)^{* *}\end{array}$ & $\begin{array}{r}-28.439 \\
(2.548)^{* *}\end{array}$ \\
\hline $\begin{array}{l}\text { Observations } \\
\text { Number of id }\end{array}$ & $\begin{array}{r}168,174 \\
10,739\end{array}$ & 168,174 & $\begin{array}{r}5,326 \\
210\end{array}$ & 5,326 & $\begin{array}{r}1,628 \\
91\end{array}$ & 1,628 \\
\hline R-squared & 0.14 & 0.43 & 0.66 & 0.92 & 0.80 & 0.94 \\
\hline
\end{tabular}

Standard errors in parentheses

* significant at $5 \%$; ** significant at $1 \%$ 
The following graphs illustrate the above results (the first graph for fixed effects estimators and the second for OLS estimators):

\section{The Effect of Non-EMU Currency Unions and of EMU on Bilateral Trade over Time:}

Fixed Effects Estimators

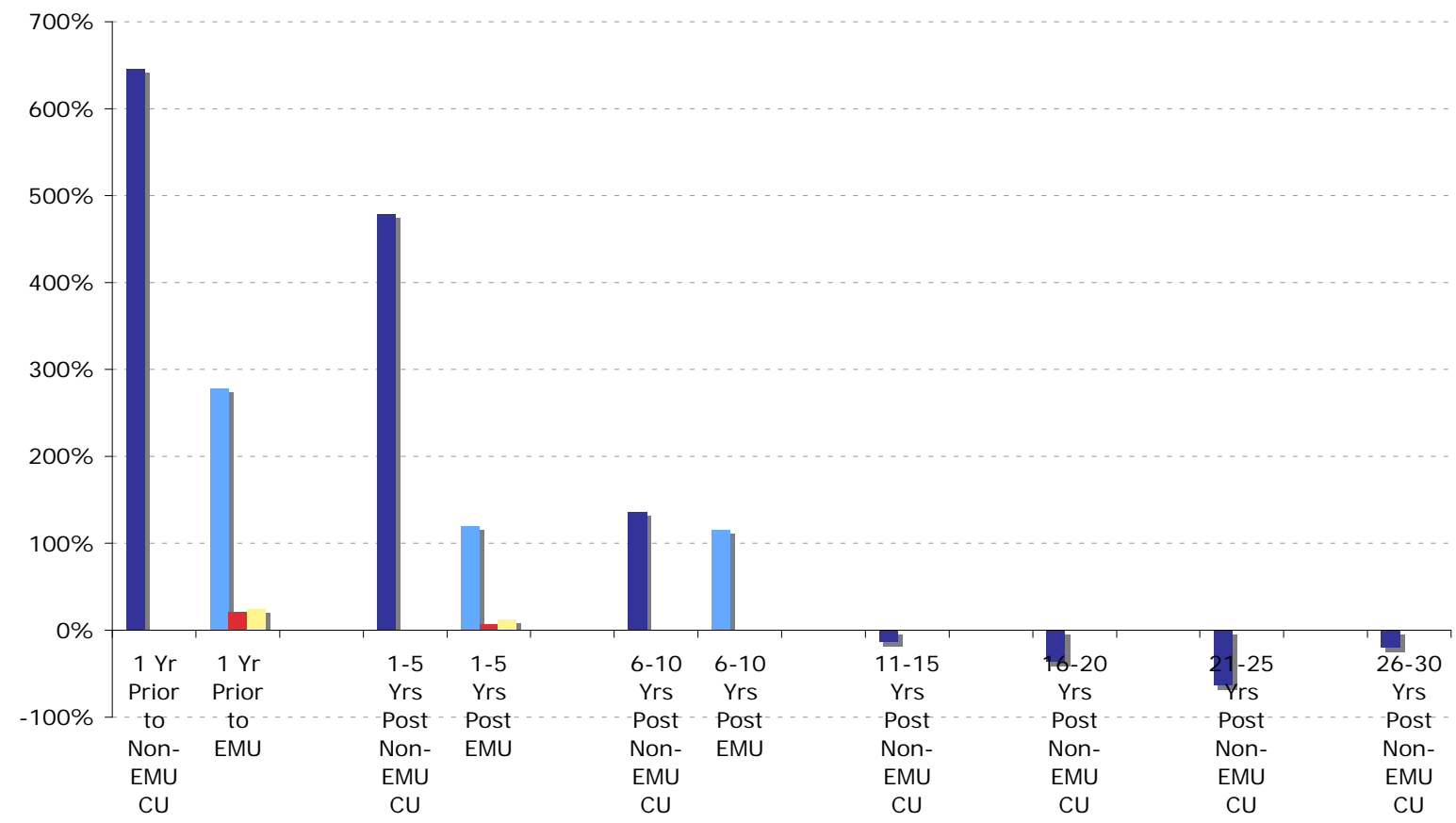

Full Sample Fixed Effects Estimator Developed Sample Fixed Effects Estimator EU Sample Fixed Effects Estimator

The Effect of Non-EMU Currency Unions and of EMU on Bilateral Trade over Time:

OLS Estimators

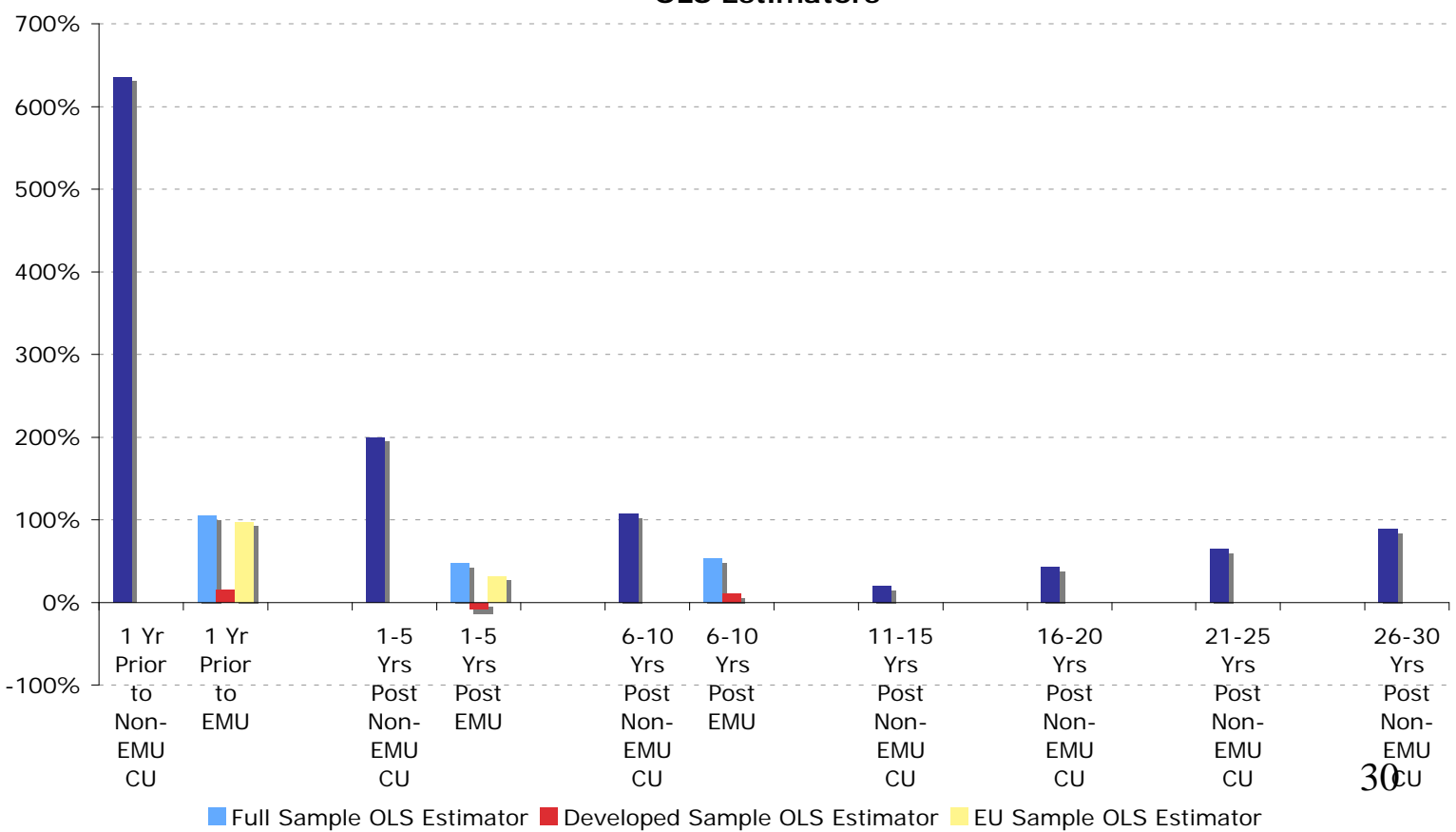




\section{The CFA Experiment}

Table 7A:

The Impact of EMU on Bilateral Trade between CFA and EMU Members, 1948-2006

Note: Dummy for CFA-EMU countrypairs takes on value 1 from 1999 onward

CFA Natural Experiment: The I mpact of EMU on Trade Between CFA and EMU Countries

1948 - 2006, OLS Estimator with Year Fixed Effects.

Dependent Variable:

Currency Union

EMU

Both Countries in European Union

Both Countries in CFA Franc Area (West and Central African)

One Country in CFA Franc Area, the Other in EMU

One Country in CFA, One Country in EMU x 1980

One Country in CFA, One Country in EMU x 1981

One Country in CFA, One Country in EMU $\times 1982$

One Country in CFA, One Country in EMU $\times 1983$

One Country in CFA, One Country in EMU $\times 1984$

One Country in CFA, One Country in EMU $\times 1985$

One Country in CFA, One Country in EMU $\times 1986$

One Country in CFA, One Country in EMU $\times 1987$

One Country in CFA, One Country in EMU x 1988

One Country in CFA, One Country in EMU x 1989

One Country in CFA, One Country in EMU x 1990

One Country in CFA, One Country in EMU $\times 1991$

One Country in CFA, One Country in EMU x 1992

One Country in CFA, One Country in EMU x 1993

One Country in CFA, One Country in EMU x 1994

One Country in CFA, One Country in EMU x 1995

One Country in CFA, One Country in EMU x 1996

One Country in CFA, One Country in EMU x 1997

One Country in CFA, One Country in EMU x 1998

One Country in CFA, One Country in EMU $\times 1999$

One Country in CFA, One Country in EMU $\times 2000$

One Country in CFA, One Country in EMU $\times 2001$

One Country in CFA, One Country in EMU $\times 2002$

One Country in CFA, One Country in EMU $\times 2003$

One Country in CFA, One Country in EMU x 2004

One Country in CFA, One Country in EMU $\times 2005$

One Country in CFA, One Country in EMU $\times 2006$

Log of Product of Real GDPs

Log of Product of Real GDPs per capita

Common Language

Common Land Border

Free Trade Agreement

Landlocked

Log of Product of Land Areas

Common Colonizer post 1945

Currently in Colonial Relationship

Ever in Colonial Relationship

Same Nation/Perennial Colonies

Real Exchange Rate of Country 1

Real Exchange Rate of Country 2

Constant 
Table 7B: $\quad$ CFA Experiment:

The Impact of EMU on Bilateral Trade between CFA and EMU Members

With Year Interactions, 1948-2006

CFA Natural Experiment: The I mpact of EMU on Trade Between CFA and EMU Countries 1948 - 2006, OLS Estimator with Year Fixed Effects.

Dependent Variable:

Log of Bilateral Trade

Currency Union

$1.706 * * *$

$(0.385)$

EMU

$0.917 * * *$

Both Countries in European Union

$(0.132)$

$-0.275$

(0.206)

Both Countries in CFA Franc Area (West and Central African)

$-0.731^{*}$

One Country in CFA Franc Area, the Other in EMU

$(0.438)$

Log of Product of Real GDPs

(0.119)

$0.812 * * *$

$(0.016)$

Log of Product of Real GDPs per capita

$-0.026$

(0.019)

Common Language

$0.355 * * *$

(0.073)

Common Land Border

$2.507 * * *$

Free Trade Agreement

$1.951 * * *$

(0.181)

Landlocked

$-0.265 * * *$

(0.049)

Log of Product of Land Areas

$-0.106 * * *$

Common Colonizer post 1945

$(0.012)$

Currently in Colonial Relationship

$0.765 * * *$

(0.106)

$-0.527 * *$

Ever in Colonial Relationship

$(0.230)$

$1.036 * * *$

(0.151)

Same Nation/Perennial Colonies

$(0.431)$

Real Exchange Rate of Country 1

$-0.002$

(0.008)

Real Exchange Rate of Country 2

$-0.004$

(0.008)

Constant

Observations

169,561

R-squared

0.40

Robust standard errors in parentheses, clustered on countrypairs.

* significant at $10 \%$; $* *$ significant at $5 \%$; $* * *$ significant at $1 \%$ 